LA-14423

Approved for public release;

distribution is unlimited.

\title{
2009 LANL Radionuclide Air Emissions Report
}


Funding for this report was provided by the U.S. Department of Energy.

Edited by Hector Hinojosa of Group IRM-CAS.

Los Alamos National Laboratory, an affirmative action/ equal opportunity employer, is operated by Los Alamos National Security, LLC, for the National Nuclear Security Administration of the U.S. Department of Energy under contract DE-AC52-06NA25396.

This report was prepared as an account of work sponsored by an agency of the U.S. Government. Neither Los Alamos National Security, LLC, the U.S. Government nor any agency thereof, nor any of their employees make any warranty, express or implied, or assume any legal liability or responsibility for the accuracy, completeness, or usefulness of any information, apparatus, product, or process disclosed, or represent that its use would not infringe privately owned rights. Reference herein to any specific commercial product, process, or service by trade name, trademark, manufacturer, or otherwise does not necessarily constitute or imply its endorsement, recommendation, or favoring by Los Alamos National Security, LLC, the U.S. Government, or any agency thereof. The views and opinions of authors expressed herein do not necessarily state or reflect those of Los Alamos National Security, LLC, the U.S. Government, or any agency thereof. Los Alamos National Laboratory strongly supports academic freedom and a researcher's right to publish; as an institution, however, the Laboratory does not endorse the viewpoint of a publication or guarantee its technical correctness. 
LA-14423

Issued: June 2010

2009 LANL Radionuclide Air Emissions Report

David P. Fuehne

- Los Alamos 



\section{U.S. Department of Energy Report}

2009 LANL Radionuclide Air Emissions

Site Name: Los Alamos National Laboratory

Location: County of Los Alamos, New Mexico

\section{Operations Office Information:}

Office: Los Alamos Site Office

Address: $\quad$ U.S. Department of Energy

National Nuclear Security Administration

Los Alamos Site Office

3747 West Jemez Road

Los Alamos, NM 87544

Contact: $\quad$ Steve Fong $\quad$ Phone: (505) 665-5534

Site Information:

Operator: Los Alamos National Security, LLC

Address: $\quad$ Los Alamos National Laboratory

PO Box 1663

Los Alamos, NM 87545

Contact: David Fuehne Phone: (505) 665-8855

\section{Compliance Assessment:}

2009 Off-Site Effective Dose Equivalent: $\quad 0.55$ mrem 


\section{Executive Summary}

This report describes the reported dose from emissions of radionuclides at Los Alamos National Laboratory (LANL) for calendar year 2009. This report fulfills the requirements established by the National Emissions Standards for Hazardous Air Pollutants - Emissions of Radionuclides other than Radon from Department of Energy Facilities (Radionuclide NESHAP or Rad-NESHAP). This report is prepared by LANL's Rad-NESHAP compliance team, which is part of the Environmental Protection Division. The information in this report is required under the Clean Air Act and is being reported to the U.S. Environmental Protection Agency (EPA). The highest effective dose equivalent (EDE) to an off-site member of the public was calculated using procedures specified by the EPA and described in this report. LANL's EDE was 0.55 mrem for 2009. The annual limit established by the EPA is 10 mrem per year.

During calendar year 2009, LANL continuously monitored radionuclide emissions at 26 "major" release points, or stacks. The Laboratory estimates emissions from an additional 58 "minor" release points using radionuclide usage source terms in lieu of stack monitoring. Also, LANL uses a network of air samplers around the Laboratory perimeter to monitor ambient airborne levels of radionuclides. To provide data for dispersion modeling and dose assessment, LANL maintains and operates meteorological monitoring systems. From these measurement systems, a comprehensive evaluation is conducted to calculate the EDE for the Laboratory.

The EDE is evaluated as any member of the public at any off-site location where there is a residence, school, business, or office. In 2009, this location was the East Gate area, immediately downwind from the Los Alamos Neutron Science Center (LANSCE) accelerator facility. Significant contributors to the reported off-site dose included emissions of short-lived radioactive gases from the LANSCE facility and the potential emissions from non-monitored (minor) emissions sources throughout the Laboratory. Doses reported to the EPA for the past 10 years are shown in Table E1. 
Table E1. Ten-Year Summary of Rad-NESHAP Dose Assessment for LANL

\begin{tabular}{ccl} 
Year & $\begin{array}{c}\text { EDE } \\
(\mathbf{m r e m})\end{array}$ & \multicolumn{1}{c}{ Highest EDE Location } \\
\hline 2000 & 0.64 & 2470 East Road ("East Gate") \\
2001 & 1.84 & 2470 East Road ("East Gate") \\
2002 & 1.69 & 2470 East Road ("East Gate") \\
2003 & 0.65 & 2470 East Road ("East Gate") \\
2004 & 1.68 & 2470 East Road ("East Gate") \\
2005 & 6.46 & 2470 East Road (“East Gate") \\
2006 & 0.47 & Los Alamos Airport Terminal \\
2007 & 0.52 & DP Road, Airnet Station 71 \\
2008 & 0.55 & 2470 East Road ("East Gate") \\
2009 & 0.55 & 2470 East Road ("East Gate") \\
\hline
\end{tabular}

\section{Significant Events}

Several events that took place in 2009 are worth discussion in this Executive Summary.

EPA approval granted for cleanup at Materials Disposal Area B. In late 2008, the Los Alamos Site Office requested approval for cleanup operations at Materials Disposal Area B (MDA-B). ${ }^{\mathrm{a}}$ Approval was granted in February 2009. Subsequent work scope changes resulted in an update to this Pre-Construction approval, which was submitted in January $2010^{\mathrm{b}}$ and approved in February 2010. Initial operations began in February 2010, with major excavation expected to commence in June 2010.

Cleanup work under the American Reinvestment and Recovery Act (ARRA). LANL has two major projects taking place under the ARRA, also known as the federal "stimulus" funding program. The first is the cleanup of MDA-B, described above. The second is the demolition and cleanup of legacy buildings at Technical Area (TA) 21 and associated subsurface areas. Funding was received in the summer of 2009, and cleanup activities began later in the year. The Rad-NESHAP program performed a review of this work in advance of the cleanup activities. Two new Airnet stations were installed to complete the monitoring of these activities, which are non-point (diffuse) emission sources. The complete review is documented in LA-UR-09-07922, "Rad-NESHAP Review of TA-21 Remediation

a LA-UR-08-04020, "Application for Pre-Construction Approval for Compliance with 40 CFR 61 Subparts A and $\mathrm{H}$ for the Materials Disposal Area B Removal, Characterization, and Restoration Project." Submitted to EPA Region 6 on December 31, 2008. EPA approval granted February 6, 2009. Files are on ENV-ES Rad-NESHAP file server.

b LA-UR-10-00015, “Update to Pre-Construction Application for the MDA-B Project." Submitted to EPA Region 6 on January 13, 2010. EPA approval granted February 18, 2010. Files are on ENV-ES Rad-NESHAP file server. 


\section{LANL Radionuclide Air Emissions Report}

Activities." This document was submitted as courtesy notification to EPA Region 6 in May 2010, when demolition of major TA-21 radiological buildings commenced.

Scale model testing of new exhaust systems at TA-54. Waste processing operations at TA-54 are accelerating as the area approaches its 2013 scheduled closure. Two new exhaust systems were designed and installation begun for radiological emissions operation in 2010. To certify the sample system design and location under American National Standards Institute/Health Physics Society (ANSI/HPS) N13.1-1999, scale model testing was performed in 2009-2010. The scale model was tested for uniformity in flow velocity, tracer gas concentration, and aerosol concentration. To validate the scale model results for use on the actual as-built stack, the flow velocity profile of the as-built stack was measured in May 2010. The results met criteria in ANSI/HPS N13.1-1999 for use of scale model emissions testing to certify emissions sampling locations in new stacks. Since both buildings in which this new exhaust system will be deployed have housed radiological operations in the past, and since this represents existing/ongoing/relocation of waste processing work, no pre-construction notification is required from the EPA. Notifications of planned startup for each building were submitted to EPA Region 6 in the first half of 2010.

External assessment of the Rad-NESHAP program. In June 2009, the LANL Rad-NESHAP program hosted an external assessment of specific areas of the project. Under scrutiny were the readiness for operations at MDA-B, the emissions tracking program at the Isotope Production Facility at TA-53, the use of the new Version 3 of CAP88-PC, and LANL's response to issues identified in the previous external assessment in 2007. The program was found to be in good shape overall, with specific issues identified to improve the quality of the program and its compliance status.

Site visit by EPA Region 6. Following up on the external assessment, LANL hosted a site visit by EPA Region 6 in September 2009. In addition to reviewing the assessment results the regional representative attended a meeting of citizen organizations hosted by the New Mexico Environment Department and toured the newly constructed Radiological Laboratory/Utility/Office Building, which is the first phase of the Chemistry and Metallurgy Research Replacement program. The representative also toured MDA-B and TA-21 projects described above and reviewed air monitoring plans and associated emissions trending protocols that have been developed to ensure LANL maintains its compliance posture during these cleanup activities. Finally, discussions were held with representatives of TA-54 waste processing activities and the associated emissions sampler scale model testing, both described above.

Hail storm damages TA-6 meteorological tower. In early July 2009, a serious hail storm crossed through Los Alamos County. In addition to causing widespread damage to vehicles and 
residences throughout the County, the storm damaged instruments on the TA-6 meteorological tower. This tower is the source of the majority of meteorological data used in CAP88 modeling of emissions and calculating off-site doses. Repairs to the tower were finalized in early October. However, the extended down time between July and October resulted in the tower data being insufficient for annual CAP88 analyses. To account for this, LANL instead used a five-year average of TA-6 tower data, covering years 2004 through 2008. Past studies have shown that year-to-year variability in meteorological data is small in comparison with multi-year averages. ${ }^{c}$ The complete data set appears in Table 7 of this report.

TA-16-450 tritium monitoring system issues. As described in our annual emissions report for 2007, tritium operations in the Weapons Engineering Tritium Facility (WETF) are monitored by sampling systems, called bubblers. There are plans for WETF operations at TA-16 to expand from Building 205 into additional space in Building 450. In 2007, the air exhaust from 16-205 was redirected from the old stack into the common stack at 16-450, shared by both buildings. Two redundant systems monitor emissions from this consolidated WETF stack, which is designated TA-16 Bldg-0450 Exhaust Stack (ES) 05 or 16045005 . One bubbler is in the exhaust duct leading from TA-16 Building 205 and monitors operations in Building 205 only. The second bubbler is in the ES-5 stack and monitors emissions from both Buildings 205 and 450. Operations in Building 450 have not yet begun at levels which require monitoring, so that system is not needed to meet any compliance requirements. In early 2009 , results from the bubbler system in the ES-5 stack became erratic and unstable and did not trend with the 16-205 duct bubbler as they had in past years. The stack bubbler was removed for troubleshooting and repair. For 2009, emissions are reported based on measurements from the 16-205 duct bubbler, which has been successfully in use for Rad-NESHAP compliance for over 10 years.

Review of new fuel fabrication activities at TA-3-66. The Sigma facility at TA-3 Building 66 houses the Laboratory's uranium foundry and related activities. One program ongoing at Sigma is the fabrication of uranium fuel for research nuclear reactors. In 2009, the Rad-NESHAP team was asked to review activities proposed for Sigma involving production of a new type of low-enriched uranium fuel. The proposed activities were existing and ongoing processes at Sigma, but would mean increases in throughput totals and a different uranium mixture in these processes. The result of this regulatory review was that no additional monitoring or notification requirements would be needed for the first several years of these activities, only requiring continuous monitoring if throughput exceeds levels initially planned.

c Memo RRES-MAQ:03-051, K. Jacobson to D. Fuehne, "Variability of Annual Meteorological Data Sets," dated March 11, 2003. 
2009 LANL Radionuclide Air Emissions Report 


\title{
2009 LANL Radionuclide Air Emissions Report
}

\begin{abstract}
The emissions of radionuclides from Department of Energy Facilities such as Los Alamos National Laboratory (LANL) are regulated by the Amendments to the Clean Air Act of 1990, National Emissions Standards for Hazardous Air Pollutants (40 CFR 61 Subpart H). These regulations established an annual dose limit of $10 \mathrm{mrem}$ to the maximally exposed member of the public attributable to emissions of radionuclides. This document describes the emissions of radionuclides from LANL and the dose calculations resulting from these emissions for calendar year 2009. This report meets the reporting requirements established in the regulations.
\end{abstract}

\section{Section I. Facility Information}

\subsection{4(b)(1) Name and Location of Facility}

Los Alamos National Laboratory (LANL or the Laboratory) and the associated residential areas of Los Alamos and White Rock are located in Los Alamos County in north-central New Mexico, approximately $100 \mathrm{~km}$ (60 mi) north-northeast of Albuquerque and $40 \mathrm{~km}$ (25 mi) northwest of Santa $\mathrm{Fe}$ (Figure 1).

\subsection{4(b)(2) List of Radioactive Materials Used at LANL}

Since the Laboratory's inception in 1943, its primary mission has been nuclear weapons research and development. Programs include weapons development, nonproliferation, magnetic and inertial fusion, nuclear fission, nuclear safeguards and security, and laser isotope separation. There is also basic research in the areas of physics, chemistry, engineering, and biology.

The primary facilities involved in the emissions of radioactivity are outlined in this section. The facility locations are designated by technical area (Figure 2) and building. For example, the facility designation TA-3-29 is Building 29 at Technical Area (TA) 3. Potential radionuclide release points are listed in several tables that follow. Some of the sources described below are characterized as non-point (diffuse and fugitive) emissions. Off-site doses resulting from non-point emissions of radioactive particles and tritium oxide (tritiated water vapor or HTO) are measured and calculated using LANL's ambient air sampling network (Airnet).

Radioactive materials used at LANL include weapons-grade plutonium, heat-source plutonium, enriched uranium, depleted uranium, and tritium. Also, a variety of materials are generated through the process of activation; consequent emissions occur as gaseous mixed activation products (GMAP) and other particulate or vapor activation products (P/VAP). 


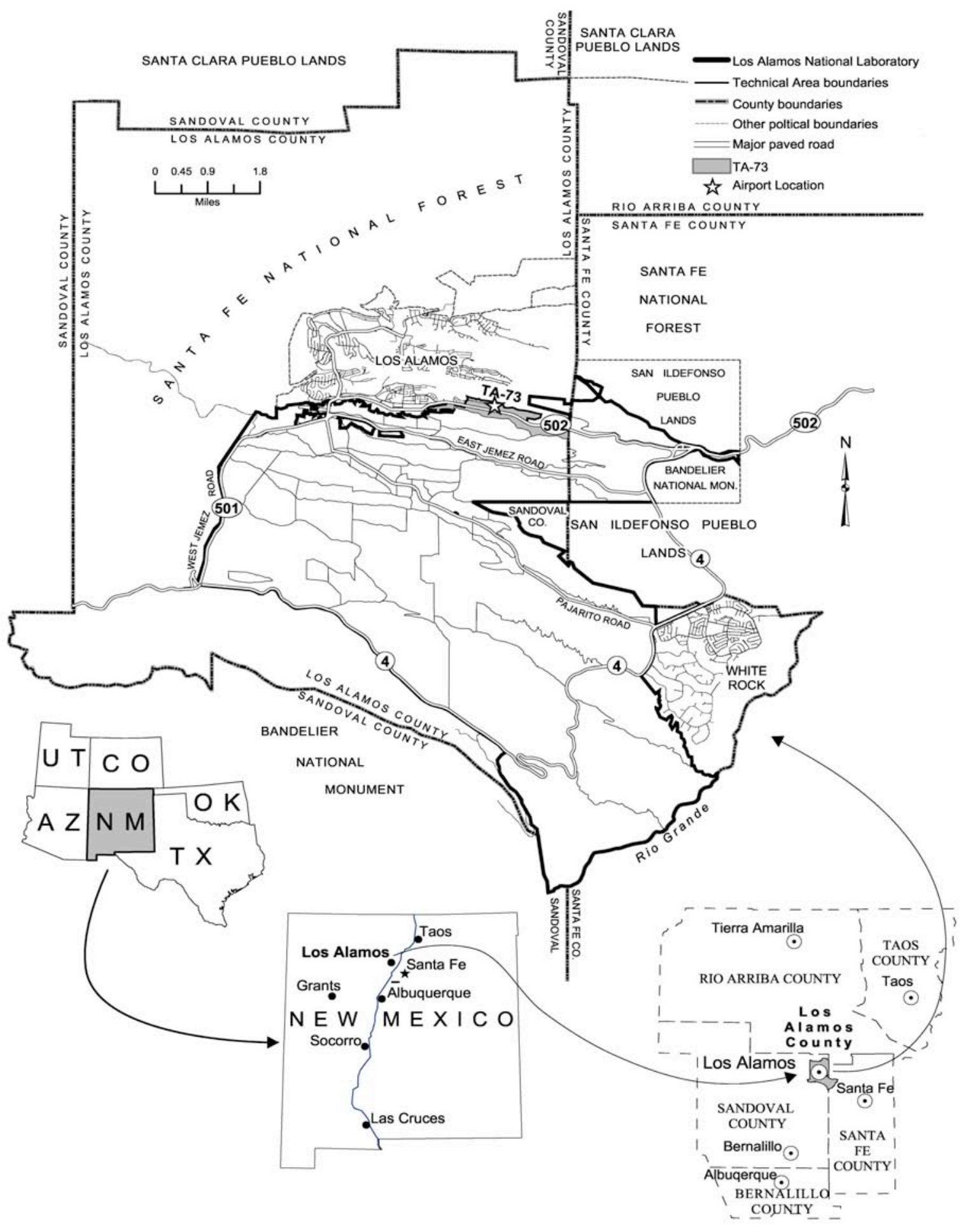

Figure 1. Location of Los Alamos National Laboratory. 


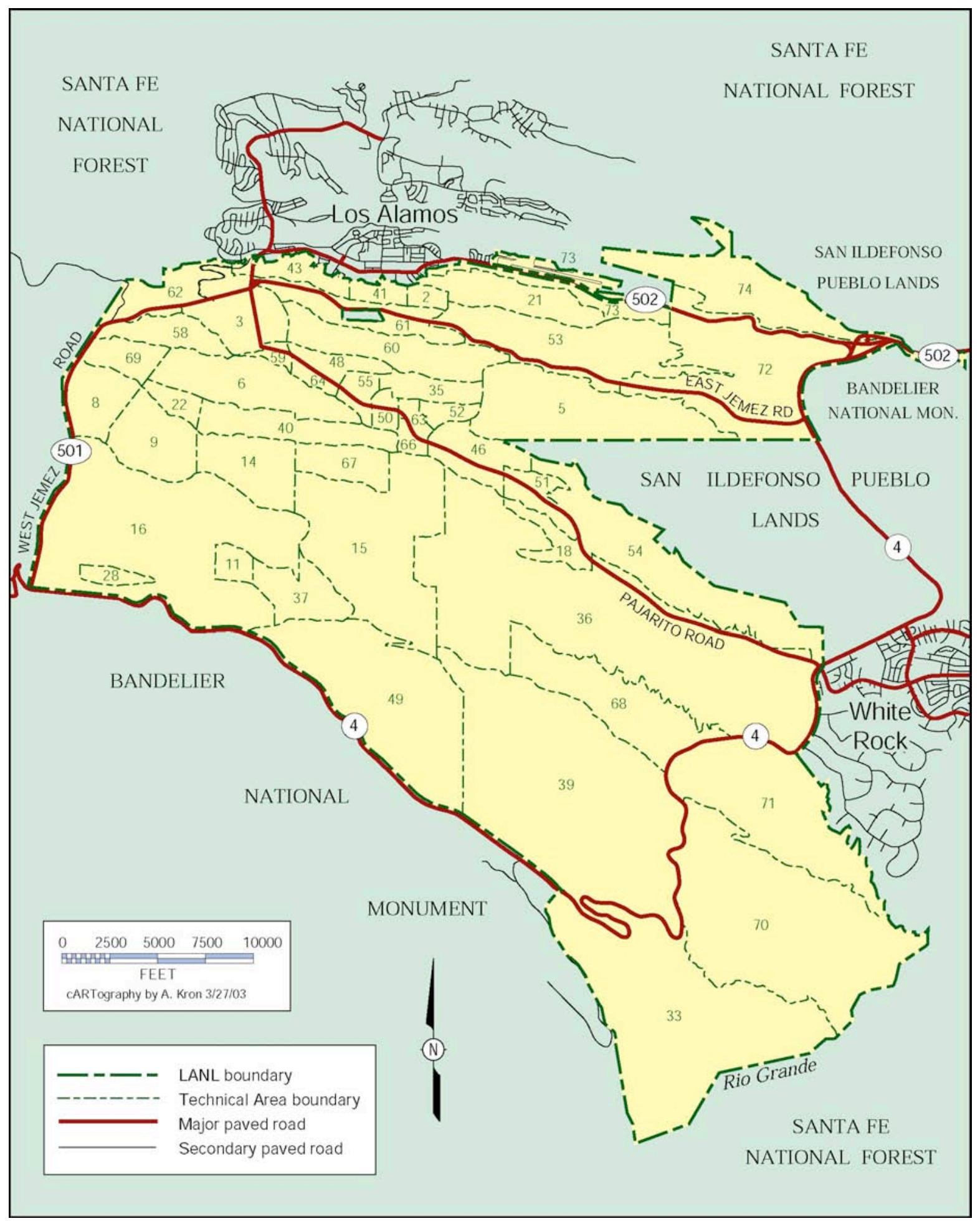

Figure 2. Los Alamos National Laboratory technical areas by number. 
The radionuclides emitted from point sources at LANL in calendar year 2009 are listed in the subsequent tables. Tritium is released as either tritiated water vapor (called HTO) or elemental tritium gas (HT). Plutonium contains traces of ${ }^{241} \mathrm{Am}$, a transformation product of ${ }^{241} \mathrm{Pu}$. Some of the uranium emissions are from open-air explosive tests involving depleted uranium. GMAP emissions include ${ }^{41} \mathrm{Ar}$, ${ }^{11} \mathrm{C},{ }^{13} \mathrm{~N}$, and ${ }^{15} \mathrm{O}$. Various radionuclides such as ${ }^{197 \mathrm{~m}} \mathrm{Hg},{ }^{68} \mathrm{Ge}$, and ${ }^{76} \mathrm{Br}$ make up the majority of the P/VAP emissions.

\subsection{4(b)(3) Handling and Processing of Radioactive Materials at LANL Technical Areas}

Additional descriptions of LANL technical areas can be found in the Annual Environmental Surveillance Report for LANL. ${ }^{1}$ More thorough descriptions of LANL operations can be found in the Annual Site-Wide Environmental Impact Statement Yearbooks, the most recent being published in 2009. ${ }^{2}$ A complete list of non-monitored sources and activities is found in the Radioactive Materials Usage Survey, described in the next section.

The primary facilities responsible for radiological airborne emissions are as follows.

TA-3-29: The Chemistry and Metallurgy Research (CMR) facility conducts chemical and metallurgical research. The principal radionuclides used are isotopes of plutonium as well as other actinides. There are a variety of activities involving plutonium and uranium, which support many LANL and other U.S. Department of Energy (DOE) programs.

TA-3-66: This facility is used for a variety of nuclear materials work, primarily for dealing with metallic and ceramic items, including depleted uranium.

TA-3-102: This machine shop is used for the metalworking of radioactive materials, primarily depleted uranium.

TA-3-1698: This facility is designated as the Materials Science Laboratory. The building was designed to accommodate a wide variety of chemicals used in small amounts that are typical of many university and industrial labs conducting research in materials science.

TA-15 and TA-36: These facilities conduct open-air explosive tests involving depleted uranium and weapons development testing.

TA-15-312: Dual-Axis Radiographic Hydrodynamic Test (DARHT) Facility: This facility conducts high-explosive-driven experiments to investigate weapons functions and behavior during nonnuclear tests using advanced radiography. Starting in 2007, explosive operations at DARHT are conducted in containment vessels. Use of these vessels virtually eliminates air emissions from these operations. 
TA-16-205 and -450: Weapons Engineering Tritium Facility (WETF): Buildings 205 and 450 were specifically designed and built to process tritium safely. The operations at WETF are divided into two categories: tritium processing and activities that support tritium processing. Examples of tritiumprocessing operations include the repackaging of tritium into smaller quantities and the packaging of tritium and other gases to user-specified pressures. Other operations include reacting tritium with other materials to form compounds and analyzing the effects of tritium. In 2007, expansion of WETF into building 450 began. During this expansion, emissions from TA-16-205 were ducted into the TA-16-450 ES-05 stack. Therefore, TA-16-205 ES-04 is discontinued as a monitored point source and TA-16-450 ES-05 will be the point source for both buildings. The exhaust stack was certified to measure emissions from building 450 whenever that portion of the complex becomes active. The monitoring system located in the duct between building 16-205 and the 16-450 stack remains active to monitor emissions from building 16-205. As discussed earlier, the ES-05 stack monitor experienced technical problems, and its operations were discontinued in June 2009. Reported emissions are measured with the 16-205 duct monitor.

TA-21: Many of the facilities at this decommissioned radiochemistry site are undergoing decontamination and demolition. Some of these operations may contribute to diffuse emissions of uranium and plutonium into the air. The tritium operations in TA-21 were relocated in 2006 to other LANL sites, primarily WETF. In 2009, demolition of office and support buildings began. Radiological buildings are being demolished in 2010.

TA-41-4: This building was formerly used as a tritium-handling facility. The tritium sources were removed in 2002. Diffuse tritium emissions could result from residual tritium contamination and cleanup operations.

TA-48-1: The principal activities carried out in this facility are radiochemical separations supporting the medical radioisotope production program, the Yucca Mountain program, nuclear chemistry experiments, and geochemical and environmental research. These separations involve nCi to Ci (hot cell) amounts of radioactive materials and use a wide range of analytical chemical separation techniques, such as ion exchange, solvent extraction, mass spectroscopy, plasma emission spectroscopy, and ion chromatography.

TA-50-1: This waste management site consists of an industrial low-level (radioactive) liquid waste treatment plant.

TA-50-37: Currently there are no operations involving radioactive material in this building; future operations may involve the use of radioactive actinides. 


\section{LANL Radionuclide Air Emissions Report}

TA-50-69: This waste management site consists of a waste characterization, reduction, and repackaging facility.

TA-53: This technical area houses the Los Alamos Neutron Science Center (LANSCE), a linear particle accelerator complex. The accelerator is used to conduct research in stockpile stewardship, radiobiology, materials science, and isotope production, among other areas. LANSCE consists of the Manuel Lujan Neutron Scattering Center, the Proton Storage Ring, the Weapons Neutron Research facilities, the Proton Radiography facility, and the high-intensity beam line (Line A). The facility accelerates protons and $\mathrm{H}$ - ions to an energy of $800 \mathrm{MeV}$ into target materials such as graphite and tungsten to produce neutrons and other subatomic particles. The design current of the accelerator is approximately 1000 microamperes. Airborne radioactive emissions result from proton beams and secondary particles passing through and activating air in target cells, beam stop, and surrounding areas, or activating water used in target cooling systems. The majority of the emissions are short-lived activation products such as ${ }^{11} \mathrm{C},{ }^{13} \mathrm{~N}$, and ${ }^{15} \mathrm{O}$. Most of the activated air is vented through the main stacks; however, a fraction of the activated air becomes a fugitive emission from the target areas. Two solar evaporative basins were constructed and began operation in 1999 to evaporate wastewater from the accelerator. Evaporation of water from these facilities can result in a diffuse source of airborne tritium.

TA-54: This waste management site consists of active and inactive shallow land burial sites for solid waste and is the primary storage area for mixed and transuranic radioactive waste. MDA G at TA54 is a known source of diffuse emissions of tritium vapor. Resuspension of soil contaminated with low levels of plutonium/americium has also created a diffuse source. Shipments of transuranic waste for disposal at the Waste Isolation Pilot Plant began in 1999. In 2009, work began to start up new waste drum repackaging operations at TA-54 to support the planned closure of the facility later this decade.

TA-55: Building 4 of the Plutonium Facility (PF-4) provides a pit manufacturing capability and continues the role providing the capability for research and development applications in chemical and metallurgical processes for recovering, purifying, and converting plutonium and other actinides. ${ }^{3}$ A wide range of activities (e.g., the heating, dissolution, forming, and welding of special nuclear materials) is also conducted. Additional activities include investigating the means to safely ship, receive, handle, and store nuclear materials and to manage wastes and residues from TA-55. Limited-scope tritium operations also take place in certain areas of TA-55. Building 2 of TA-55 houses associated support facilities for operations in PF-4, including the radiological sample analysis laboratory. Operations from this laboratory are tracked as part of LANL's non-monitored source program. 


\section{LANL Radionuclide Air Emissions Report}

\section{Section II. Air Emissions Data}

\subsection{4(b)(4) Point Sources}

Monitored and unmonitored release points at LANL are listed in Table 1. The point sources are identified using an eight-digit identification number for each exhaust stack (StackID); the first two digits represent the LANL technical area, the next four the building, and the last two digits the stack number. Also listed in Table 1 are type, number, and efficiency of the effluent controls used on the release points. Each stage of the high-efficiency particulate air (HEPA) exhaust filters is tested at least once every 12 months. The performance criteria for HEPA filter systems are a maximum penetration of $5 \times 10^{-4}$ for one stage and $2.5 \times 10^{-7}$ for two stages in series, in which penetration equals the concentration of aerosol downstream of the air cleaner divided by the upstream concentration.

In addition to the 26 monitored point sources, 58 unmonitored release points in more than 40 LANL buildings are included in Table 1. Under 40 CFR 61.93(b)(4)(i), sampling of these release points is not required because each release point has a potential effective dose equivalent (PEDE) of less than $0.1 \mathrm{mrem} / \mathrm{yr}$ at the critical receptor. However, in order to verify that emissions from unmonitored point sources remain low, LANL conducts periodic confirmatory measurements in the form of the annual Radioactive Materials Usage Survey for Unmonitored Point Sources. ${ }^{4}$ The purpose of this survey is to collect and analyze radioactive materials usage and process information for the monitored and unmonitored point sources at LANL.

The distance between each of the release points and the nearest receptor is provided in Table 1. The nearest receptor can be a residence, school, business, or office. In this report, the nearest receptor is defined as the public receptor most impacted by a given release point; that is, the air dispersion pattern is taken into account to determine the nearest or most critical receptor location.

In compliance with Appendix D to 40 CFR 61, we have used data collected from the facilities in conjunction with engineering calculations and other methods to develop conservative emissions estimates from unmonitored point sources. Estimated PEDEs are calculated by modeling these emissions estimates using the U.S. Environmental Protection Agency (EPA)-approved CAP88 dose modeling software. A comprehensive survey of all of LANL's monitored and unmonitored point sources is conducted annually or biannually, depending on the magnitude of potential emissions. The Laboratory has established administrative requirements to evaluate all potentially new sources. These requirements are established for the review of new Laboratory activities and projects, ensuring that air quality regulatory requirements will be met before the activity or project begins. ${ }^{5}$ 


\section{LANL Radionuclide Air Emissions Report}

\section{Non-point Sources}

There are a variety of non-point sources within the $111 \mathrm{~km}^{2}$ of land occupied by LANL. Nonpoint sources can occur as diffuse or large-area sources, or as leaks or fugitive emissions from facilities. Examples of non-point sources of airborne radionuclides include surface impoundments, shallow land burial sites, open burn sites, live firing sites, outfalls, container storage areas, unvented buildings, waste treatment areas, solid waste management units, and tanks. Additionally, buildings with only standard heating/ventilating/air conditioning systems and/or without active process ventilation are considered to be non-point sources.

LANL summarizes the potential impacts of non-point sources by analyzing and reporting air concentration measurements of significant radionuclides (other than activation products) collected at ambient air-sampling (Airnet) sites around the Laboratory and at locations of public receptors surrounding the Laboratory. The LANL Airnet system was approved for use in monitoring LANL's nonpoint radioactive air emission sources in $1996 .{ }^{6}$ Based on the original methodology approved by EPA, additional procedures were developed to identify when new Airnet stations were required to assure continued compliance with the National Emissions Standards for Hazardous Air Pollutants - Emissions of Radionuclides other than Radon from Department of Energy Facilities (Rad-NESHAP). ${ }^{7,8}$

\section{Radionuclide Emissions}

Radionuclides released from monitored point sources, along with the annual emissions in curies for each radionuclide, are documented in Table 2. The point sources are identified using an eight-digit identification number for each exhaust stack: the first two digits represent the LANL technical area, the next four digits the building, and the last two digits the stack number. No detectable emissions are denoted as "none." A map showing the general locations of the facilities continuously monitored for radionuclide emissions is shown in Figure 3.

\section{Pollution Controls}

The most common type of filtration for emission control purposes at LANL is the HEPA filter, as noted in Table 1. HEPA filters are constructed of sub-micrometer glass fibers that are pressed and glued into a compact, paper-like, pleated media. The media are folded alternately over corrugated separators and mounted into a metal or wood frame in eight standard sizes and airflow capacities. A Type I nucleargrade HEPA filter is capable of removing $99.95 \%$ of $0.3-\mu \mathrm{m}$ particles at rated airflow. Other types of filters used in ventilation systems are Aerosol 95; RIGA-Flow 220, 221, and 222; and FARR 30/30. 


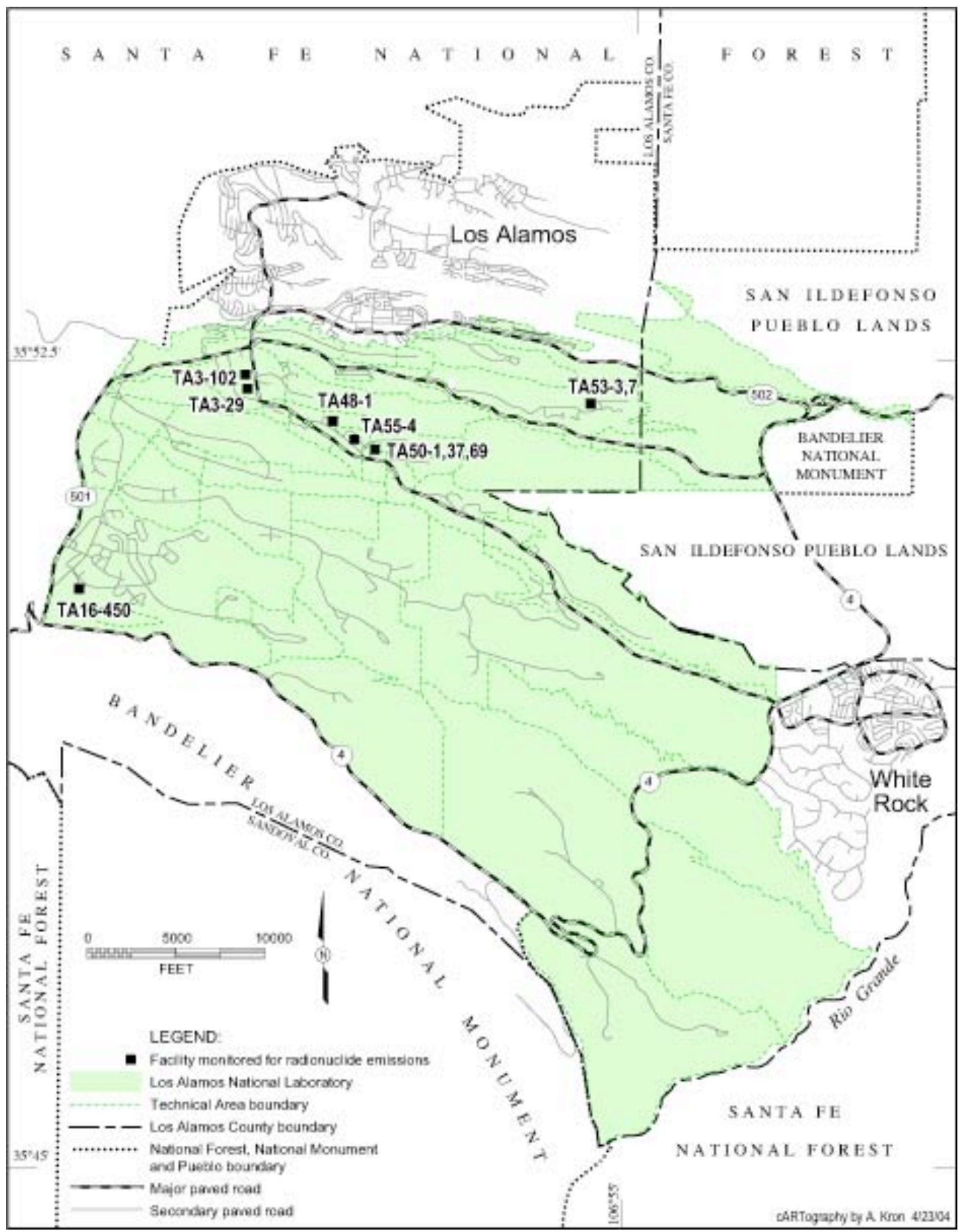

Figure 3. Location of facilities with continuously operated stack-sampling systems for radionuclide emissions. 


\section{LANL Radionuclide Air Emissions Report}

These units are typically used as prefilters in HEPA filtration systems. These filters are significantly less efficient than HEPA filters and are typically used for collecting particulate matter larger than $5 \mu \mathrm{m}$.

The above-mentioned filters are only effective for particles. When the contaminant of concern is in the form of a gas or vapors, activated charcoal beds can be used. Charcoal beds collect the gas contaminant through an adsorption process in which the gas comes in contact with the charcoal and adheres to the surface of the charcoal. The charcoal can be coated with different types of materials to make the adsorption process more efficient for different types of contaminants. Typically, charcoal beds achieve an efficiency of $98 \%$ capture.

Tritium effluent controls are generally composed of a catalytic reactor and a molecular sieve bed. Tritium-contaminated effluent is passed through a catalyst that converts HT into HTO. This HTO is then collected as water on a molecular sieve bed. This process can be repeated until the tritium level is at, or below, the desired level. The effluent is then vented through the stack.

A delay system is used to reduce some of the short-lived radionuclides generated by activation at LANSCE. Emissions from the highest source of activated gas (the off-gas system for the 1L target cooling loops) are directed into a long transport line to hold up the radionuclide gases before emission. This delay system is used to provide a reduction in radionuclide emissions from the $1 \mathrm{~L}$ target area.

\section{Compliance with Maintenance and Inspection Requirements under the Revised Rad-NESHAP}

The 2003 revisions to Subpart H established several inspection and maintenance requirements for monitored stacks. These requirements are based on American National Standards Institute/Health Physics Society N13.1-1999, Sampling and Monitoring Releases of Airborne Radioactive Substances from the Stacks and Ducts of Nuclear Facilities. Annual visual inspection of particulate monitoring systems is a component of the Laboratory's program to comply with these requirements. Of the 26 monitored stacks at LANL, we performed stack sampling system inspections on 23 of these stacks in 2009. Two stacks were not inspected because they do not require monitoring under Rad-NESHAP regulations. One additional stack is a tritium-only sampler, and per alternative method approval from EPA Region 6, we use quantitative performance tests in lieu of visual inspections for tritium systems. For tritium samplers, the measured emissions are scaled up as needed based on the results of these performance tests. Eight stack sampling systems were found to have particulate deposition and require cleaning. These systems were cleaned in 2009 or are scheduled to be cleaned as part of the 2010 inspection cycle. 
The one stack sampling system that was identified for cleaning from the 2008 inspection was cleaned during 2009. In 2009, no radiological material was measured on inspection or cleaning equipment. Therefore, no additions to the source term are required from this pathway for 2009.

\section{Section III. Dose Assessment}

\subsection{4(b)(7) Description of Dose Calculations}

Effective dose equivalent (EDE or dose) calculations for point sources, unmonitored point sources, and non-point gaseous activation products from LANSCE were performed with the CAP88 code. Starting with the 2006 annual emissions report, LANL uses CAP88-PC version 3 to demonstrate compliance. Verification of the CAP88 code is performed by running the EPA test case before running the dose calculations each day.

\section{Development of Source Term}

\section{Tritium emissions}

Tritium emissions from the Laboratory's tritium facilities are measured using a collection device known as a bubbler. This device enables the Laboratory to determine not only the total amount of tritium released but also if it is in the elemental (HT) or oxide (HTO) form. The bubbler operates by pulling a continuous sample of air from the stack, which is then "bubbled" through three sequential vials containing ethylene glycol. The ethylene glycol collects the water vapor from the sample of air, including any tritium that is part of a water molecule (tritium oxide, or HTO). After bubbling through these three vials, essentially all the HTO is removed from the air, leaving elemental tritium, or HT. The sample, containing the HT, is then passed through a palladium catalyst that converts the HT to HTO. The sample is pulled through three additional vials containing ethylene glycol, which collects the newly formed HTO. The amount of HTO and HT is determined by analyzing the ethylene glycol for the presence of tritium using liquid scintillation counting. The bubbler will discriminate HTO vapor from HT gas, allowing separate dose assessment with CAP88-PC version 3. For conservatism, however, all tritium is modeled as vapor phase HTO.

Tritium emissions from LANSCE do not require monitoring under 40 CFR 61.93(b)(4)(i). The primary source for airborne tritium emissions at LANSCE is activation of water vapor in air and activation and subsequent evaporation of water in the cooling system of beam targets. Because of the low relative contribution of tritium to the off-site dose at LANSCE, formal monitoring for tritium was discontinued after July 2001. However, the tritium emissions for 2009 can be calculated based on the rate 
of generation measured in 2001. Using these rate-of-generation calculations, the tritium emissions from LANSCE stacks in 2009 were calculated to be about $22 \mathrm{Ci}$.

\section{Radioactive particulate emissions}

Emissions of radioactive particulate matter, generated by operations at facilities such as the CMR facility (TA-3-29) and the Plutonium Facility (TA-55), are sampled using a glass-fiber filter. A continuous sample of stack air is pulled through the filter, where small particles of radioactive material are captured. These samples are analyzed weekly using gross alpha/beta counting and gamma spectroscopy to identify any increase in emissions and to identify short-lived radioactive materials. Every six months, LANL composites these stack samples for subsequent analysis at an off-site laboratory.

These composite samples are analyzed to determine the total activity of materials such as ${ }^{234} \mathrm{U},{ }^{235} \mathrm{U},{ }^{238} \mathrm{U}$, ${ }^{238} \mathrm{Pu},{ }^{239} \mathrm{Pu}$, and ${ }^{241} \mathrm{Am}$. These data are then combined with estimates of sampling losses and stack and sample flows to calculate emissions. Short-lived progeny are assumed to be emitted in secular equilibrium with their long-lived parent nuclides. In most cases, we measure for the presence of ${ }^{90} \mathrm{Sr}$ and assume that an equal amount of the progeny ${ }^{90} \mathrm{Y}$ is emitted as well.

\section{Vapor form emissions}

Vapor emissions, generated by LANSCE operations and by hot-cell activities at TA-3-29 and TA-48, are sampled using a charcoal filter or canister. A continuous sample of stack air is pulled through a charcoal filter upon which vaporous emissions of radionuclides are adsorbed. The amount and identity of the radionuclide(s) present on the filter are determined through the use of gamma spectroscopy. This information is then used to calculate emissions. Examples of radionuclides of this type include ${ }^{68} \mathrm{Ge}$ and ${ }^{76} \mathrm{Br}$.

\section{Gaseous mixed activation products (GMAP)}

GMAP emissions resulting from activities at LANSCE are measured using near-real-time monitoring data. A sample of stack air is pulled through an ionization chamber that measures the total amount of radioactivity in the sample. Specific radioisotopes are identified through the use of gamma spectroscopy and decay curves. This information is then used to calculate emissions. Radionuclides of this type include ${ }^{11} \mathrm{C},{ }^{13} \mathrm{~N}$, and ${ }^{15} \mathrm{O}$. 


\section{LANL Radionuclide Air Emissions Report}

\section{Summary of Input Parameters}

EDE to potential receptors was calculated for all radioactive air emissions from sampled LANL point sources. Input parameters for these point sources are provided in Table 3. The geographic locations of the release points, given in New Mexico State Plane coordinates, are provided in Table 4. The relationship of the highest receptor location to the individual release points are provided in Table 5. Other site-specific parameters and the sources of these data are provided in Table 6.

LANL operates an on-site network of meteorological monitoring towers. Data gathered by the towers are summarized and formatted for input to the CAP88 program. For 2009, data from two different towers were used for the air-dispersion modeling; the tower data that are most representative of the release point are applied. Copies of the meteorological data files used for the 2009 dose assessment are provided in Table 7. As described earlier, in July 2009, a hailstorm damaged some meteorological data acquisition equipment at the TA- 6 tower. For this reason, we did NOT use 2009 data from this tower; instead, we used five-year average data (2004-2008) from the TA-6 tower when modeling emissions for which the TA-6 tower is applicable.

The Laboratory also inputs population array data to the CAP88 program. The data file represents a 16-sector polar-type array, with 20 radial distances for each sector. Population arrays are developed for each release point using U.S. Census data, updated with annual projections from the New Mexico Bureau of Business and Economic Research. An example of the population array used for the LANSCE facility is provided in Table 8. For agricultural array input, LANL is currently using the default values in CAP88. Finally, the radionuclide inputs for the point sources monitored in 2009 are provided in Table 2.

\section{Public Receptors}

Compliance with the annual dose standard is determined by calculating the highest EDE to any member of the public at any off-site point where there is a residence, school, business, or office. The Laboratory routinely evaluates public areas to assure that any new residence, school, business, or office is identified for the EDE calculation. As per EPA guidance, ${ }^{9}$ personnel that work in leased space within the boundaries of the Laboratory are not considered members of the public for the EDE determination. Personnel of this type are considered to be subcontractors to DOE, similar to security guards and maintenance workers. 


\section{Point Source Emissions Modeling}

The CAP88 version 3 program was used to calculate doses from both the monitored and unmonitored point sources at LANL. The CAP88 program uses on-site meteorological data to calculate atmospheric dispersion and transport of the radioactive effluents. CAP88 includes all radionuclides for which there are dose conversion factors in the EPA's Federal Guidance Reports. ${ }^{10,11,12}$ In 2009, only three monitored radionuclides were not included in CAP88 for the monitored stacks source term: ${ }^{10} \mathrm{C},{ }^{14} \mathrm{O}$, and ${ }^{16} \mathrm{~N}$. For ${ }^{10} \mathrm{C}$ and ${ }^{14} \mathrm{O},{ }^{11} \mathrm{C}$ was used as a surrogate, as described in the Laboratory procedure ENVEAQ-512. ${ }^{13}$ CAP88 was used to calculate the ${ }^{11} \mathrm{C}$ dose, which was then adjusted for the number of curies emitted, the gamma energy emitted per decay, and the half life of the radionuclides. For ${ }^{16} \mathrm{~N},{ }^{28} \mathrm{Al}$ was used as the surrogate nuclide and the resulting dose was adjusted accordingly. The maximum dose from emissions of radionuclides not included in the CAP88 library was 2.25E-05 mrem. This dose contribution is well below the criteria for individual nuclide monitoring, which is $10 \%$ of a source's PEDE. Updates of 2009 "non-CAP88 nuclides" for monitored and non-monitored point sources will be described in an upcoming memo to EPA Region 6 later this summer.

\section{LANSCE Fugitive Emission Modeling}

Some of the GMAP created at the accelerator target cells or at other accelerator beam line locations migrate into room air and into the environment. These fugitive sources are continuously monitored throughout the beam-operating period. In 2009, approximately $63 \mathrm{Ci}$ of ${ }^{11} \mathrm{C}$ and $2.6 \mathrm{Ci}$ of ${ }^{41} \mathrm{Ar}$ were released from LANSCE as fugitive emissions. ${ }^{14}$ These sources were modeled as area sources using CAP88. Fugitive effluents were modeled from two areas at LANSCE, and the additional source information is provided in Table 9.

\section{Environmental Data Used for Non-point Source Emission Estimation}

The net annual average ambient concentration of airborne radionuclides measured at 26 air sampling stations (Figure 4) is calculated by subtracting an appropriate background concentration value. ${ }^{15}$ The net concentration at each air sampler is converted to the annual EDE using Table 2 of Appendix E of 40 CFR 61 and applying the valid assumption that each table value is equivalent to $10 \mathrm{mrem} / \mathrm{yr}$ from all appropriate exposure pathways (100\% occupancy assumed at the respective location). ${ }^{16}$ Dose assessment results from each air sampler are given in Table 10. The operational performance and analytical completeness of each air sampler is provided in Table 11.

In addition to ambient air sampling, the project reviewed one non-point tritium release from TA-16, in which legacy waste equipment was inventoried and processed for disposal. This resulted in a 


\section{LANL Radionuclide Air Emissions Report}

small release of tritium, approximately $12 \mathrm{Ci}$. Since the off-site dose impact from this release is less than 0.01 mrem and the emission was measured by ambient air monitoring stations, we are not including this release with the radioactive gas releases in Table 9.

\section{LANSCE Monthly Assessments}

The Laboratory evaluates and reports the dose from short-lived radioactive gases released from LANSCE exhaust stack 53000702 on a monthly basis. This is so we can track the emissions and identify any issues that need addressing. The monthly dose values are evaluated with the actual meteorology for the month and these doses are shown in Table 12. For 2009 the Laboratory also evaluated this stack's total gaseous emissions for the year in a single CAP88 run and compared the results to the monthly values summed for the calendar year. The sum of monthly doses resulted in a dose of $0.213 \mathrm{mrem}$, while the annual total single analysis resulted in a total of $0.194 \mathrm{mrem}$. All doses were evaluated at the East Gate receptor location. The values show satisfactory agreement. Since the sum of the monthly runs resulted in a slightly higher dose in 2009 , this value was conservatively used for reporting purposes.

\section{Highest EDE Determination}

For most of the recent past, the maximally exposed individual (MEI) location has been at 2470 East Road, usually referred to as "East Gate." The dose was mostly a result of LANSCE emissions. Because the LANSCE emissions after 2005 have been reduced to such low levels, the location of the MEI is not as readily apparent as in the past and required more detailed evaluation, as follows.

We know that the dose from LANSCE emissions is a significant contributor at the East Gate location, but much less so at other possible MEI locations. So we evaluated the sum of monthly LANSCE facility 53000702 GMAP emissions contribution from Table $12(0.213 \mathrm{mrem})$ and added to it the contribution from the East Gate Airnet station $(0.039 \mathrm{mrem})$ for a total of $0.252 \mathrm{mrem}$. We used this value as a point of comparison for examining the dose at other Airnet locations (see Table 10) summed with the dose from the 53000702 annual GMAP emissions at those locations.

Two Airnet stations with relatively higher doses located at places of a business or residence close to LANSCE were considered. They are Airnet station 32, the Los Alamos County Landfill office, and station 66, the former Los Alamos Inn on Trinity Drive. The Airnet doses for each station were 0.100 mrem and 0.142 mrem, respectively. The doses from the 53000702 annual GMAP emissions at these locations were $0.00614 \mathrm{mrem}$ and $0.00831 \mathrm{mrem}$, respectively. The sums of the Airnet dose and 53000702 annual GMAP emissions contribution dose at each location were $0.106 \mathrm{mrem}$ at the County 


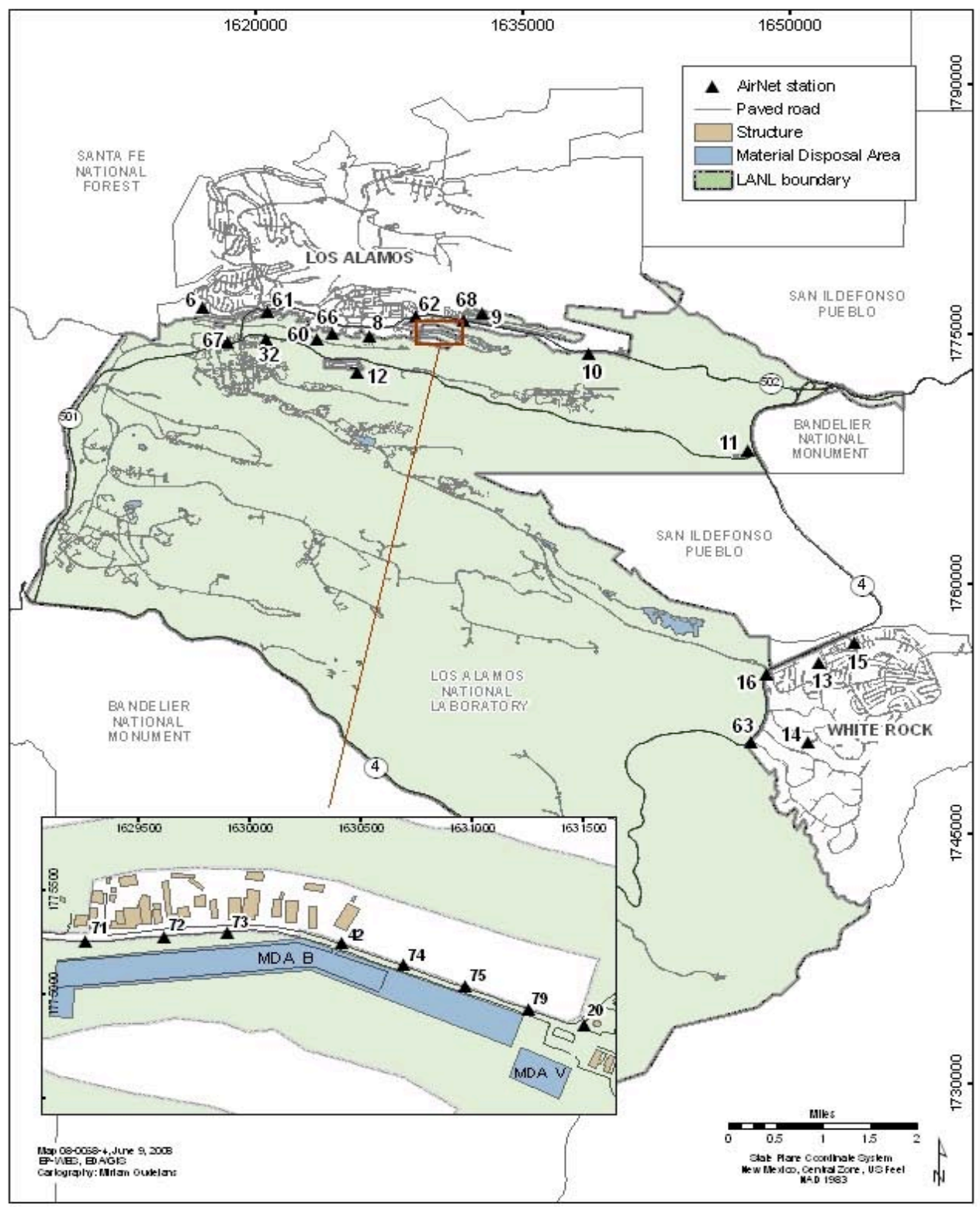

Figure 4. Locations of air sampling stations used for non-point source emissions compliance. 
Landfill and 0.150 mrem at the Los Alamos Inn. The dose of 0.252 mrem at East Gate was higher so it is the MEI location for 2009 operations.

\subsection{Compliance Assessment}

The highest EDE to any member of the public at any off-site point where there is a residence, school, or business was 0.55 mrem for radionuclides released by LANL in 2009. This dose was calculated by adding up the doses for each of the point sources at LANL, the diffuse and fugitive gaseous activation products from LANSCE, and the dose measured by the ambient air sampler in the vicinity of the public receptor location. The compliance assessment also includes a potential dose contribution of 0.246 mrem from unmonitored stacks. Because the emissions estimates do not account for pollution control systems, the actual dose will be significantly less for these unmonitored point sources. Also, this dose includes a minor contribution from radionuclides not included in CAP88. Table 13 of this report provides the compliance assessment summary. The location of the off-site point of highest EDE for 2009 was 2470 East Road, usually referred to as "East Gate."

\section{Section IV. Construction and Modifications}

\subsection{4(b)(8) Construction, Modifications, and 61.96 Activity Relocations}

Under 61.94(b)(8), there was no construction nor any modifications that were completed in calendar year 2009 for which the requirement to apply for approval to construct or modify was waived under 61.96. Similarly, there were no activity relocations and there were no first-time uses of radionuclides in existing buildings indentified in calendar year 2009.

\section{Section V. Additional Information}

This section is provided pursuant to DOE guidance and is not required by Subpart $\mathrm{H}$ reporting requirements.

\section{Unplanned Releases}

During 2009, the Laboratory had no instances of increased airborne emissions of radioactive materials that required reporting to the EPA. There were no instances of an unplanned event. 


\section{LANL Radionuclide Air Emissions Report}

\section{Environmental Monitoring}

In addition to the Airnet monitors identified in this report, additional environmental monitoring stations are operated at LANL and include several environmental monitoring stations located near the LANSCE boundary inhabited by the public. Measurement systems at these stations include thermoluminescent dosimeters, continuously operated air samplers, and in-situ high-pressure ion chambers. The combination of these measurement systems allows for monitoring of radionuclide air concentrations and the radiation exposure rate. Results for air sampling associated with NESHAP compliance are included in this document, while results for all monitoring data are published in the Annual Environmental Surveillance Report for DOE Order compliance. This can be found on the web at the following URL: http://www.lanl.gov/environment/air/reports.shtml

\section{Other Supplemental Information}

The following information is included for completeness, but not directly required under $40 \mathrm{CFR}$ 61 Subpart H regulations.

- 80-km collective effective (population) dose equivalent for 2009 airborne releases: 0.566 person-rem

- Compliance with Subparts Q and T of 40 CFR 61-Radon-222 Emissions

These regulations apply to ${ }^{222} \mathrm{Rn}$ emissions from DOE storage/disposal facilities that contain byproduct material. "By-product material" is the tailings or wastes produced by the extraction or concentration of uranium from ore. Although this regulation targets uranium mills, LANL has likely stored small amounts of by-product material used in experiments in the TA-54 low-level waste facility, MDA G; this practice makes the Laboratory subject to this regulation. Subject facilities cannot exceed an emissions rate of $20 \mathrm{pCi} / \mathrm{m}^{2}$ s of ${ }^{222} \mathrm{Rn}$. In 1993 and 1994, LANL conducted a study to characterize emissions from the MDA G disposal site. ${ }^{17}$ This study showed an average emission rate of $0.14 \mathrm{pCi} / \mathrm{m}^{2} \mathrm{~s}$ for MDA G. The performance assessment for MDA G has determined that there will not be a significant increase in ${ }^{222} \mathrm{Rn}$ emissions in the future. ${ }^{18}$

- Potential to exceed 0.1 mrem from LANL sources of ${ }^{222} \mathrm{Rn}$ or ${ }^{220} \mathrm{Rn}$ emissions: not applicable at LANL.

- Status of compliance with EPA effluent monitoring requirements as of June 3, 1996: LANL is in compliance with these requirements. 
2009 LANL Radionuclde Air Emissions Report

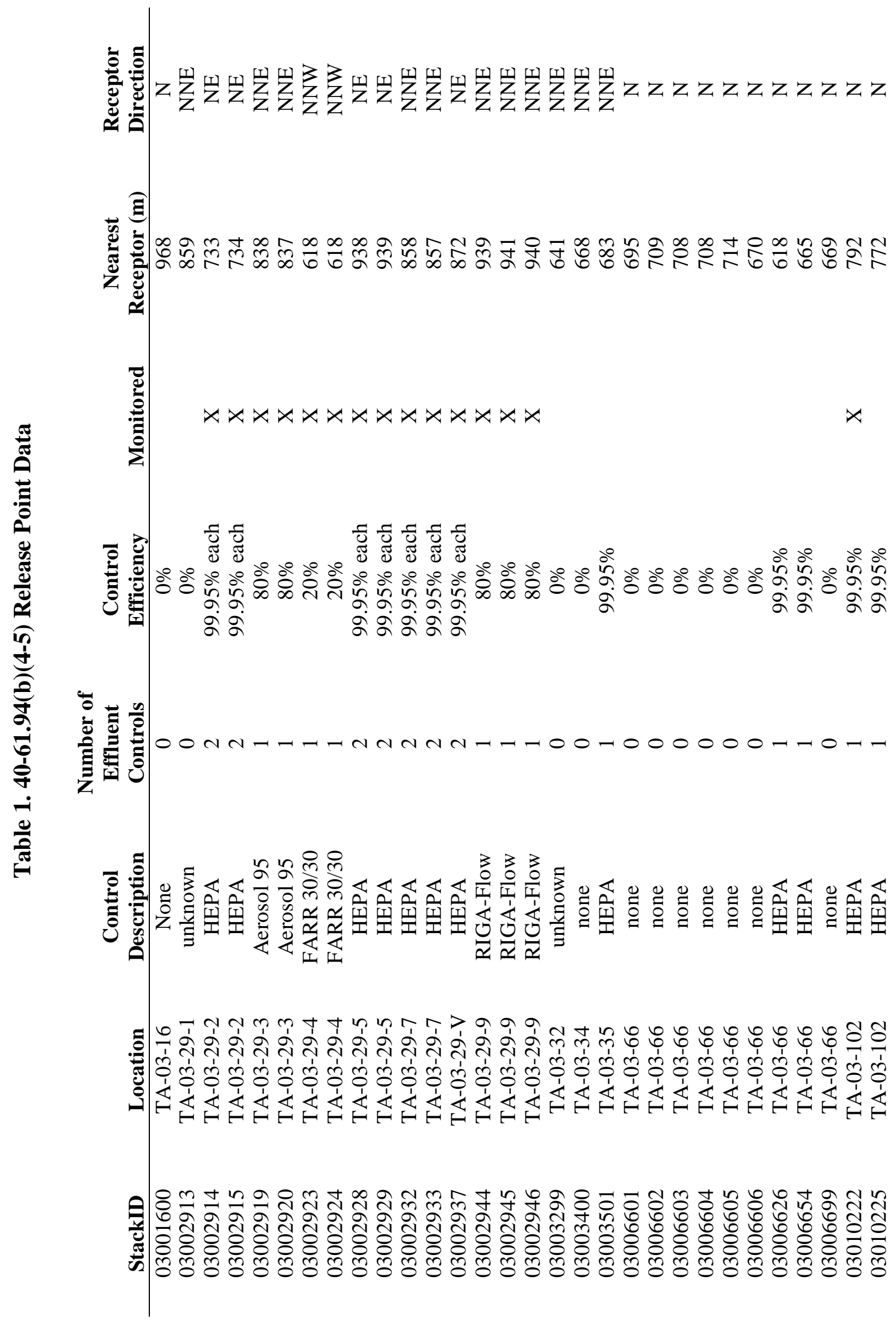




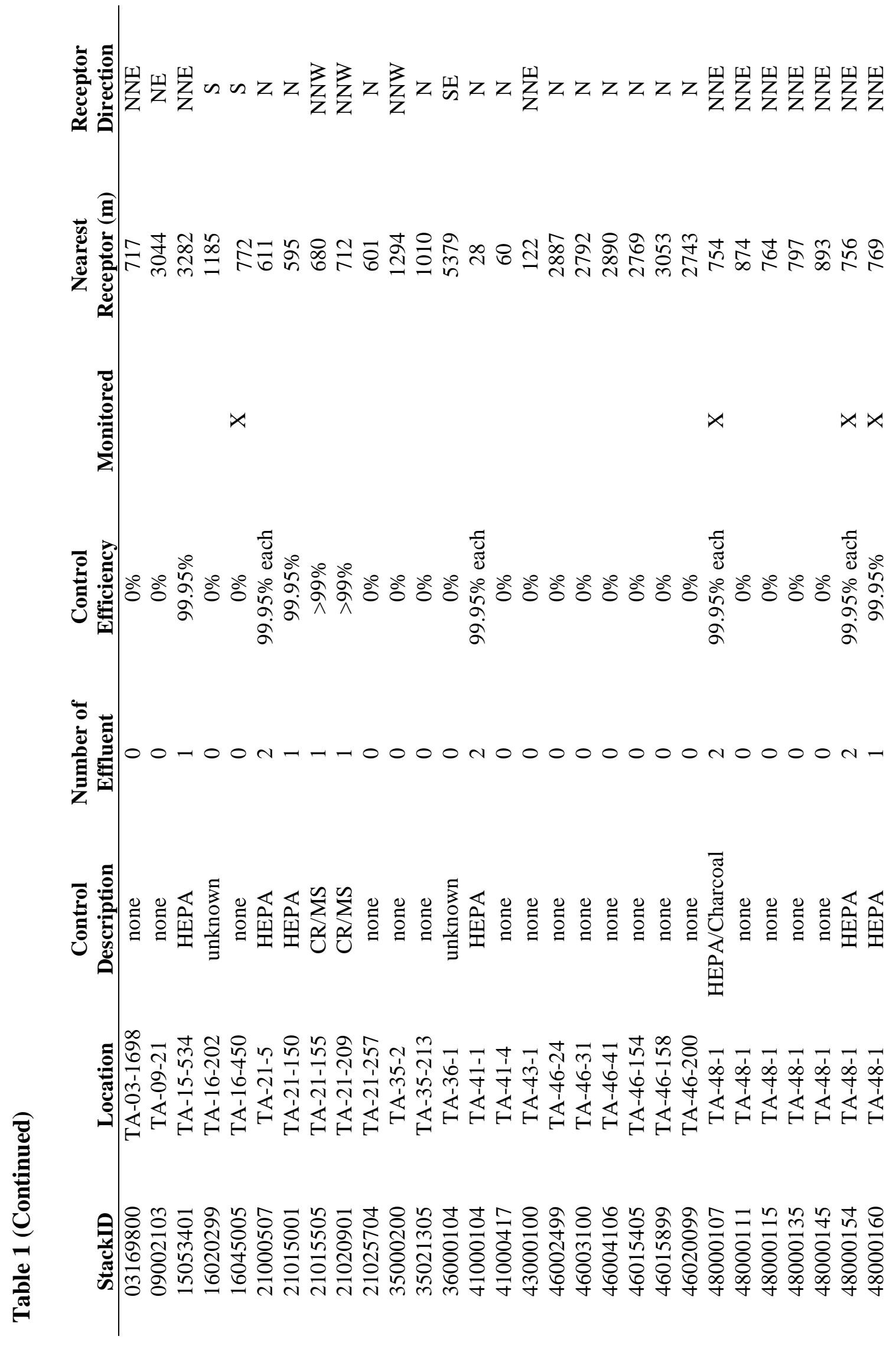




\section{LANL Radionuclide Air Emissions Report}

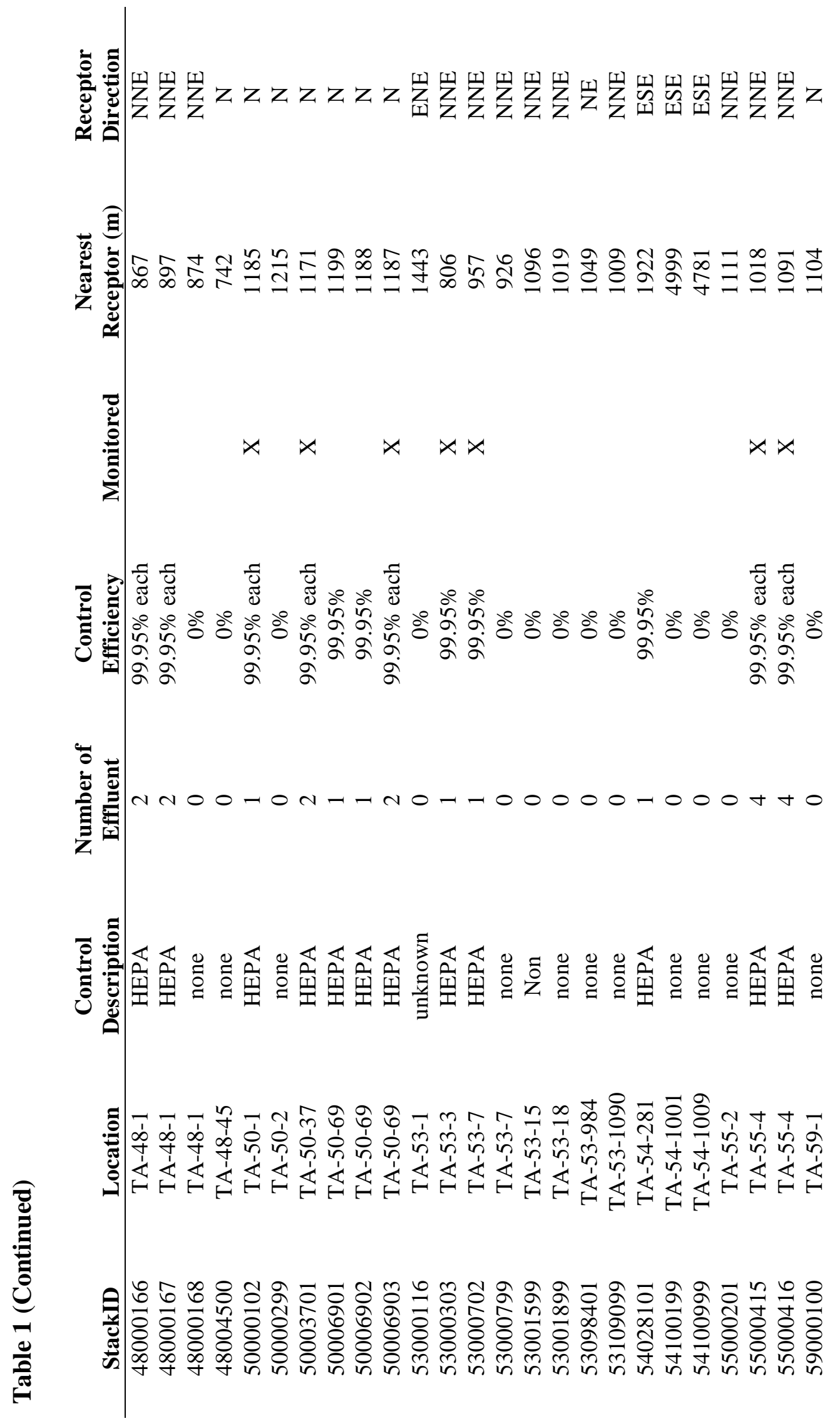


Table 2. 40-61.94(b)(7) User Supplied Data-Radionuclide Emissions

\begin{tabular}{|c|c|c|c|c|c|}
\hline StackID & Nuclide & Emissions (Ci) & StackID & Nuclide & Emissions (Ci) \\
\hline 03002914 & Am-241 & 4.77E-09 & 48000154 & None & $0.00 \mathrm{E}+00$ \\
\hline 03002914 & Pu-238 & 6.89E-07 & 48000160 & As-73 & 1.68E-07 \\
\hline 03002914 & Pu-239 & $1.75 \mathrm{E}-08$ & 48000160 & Ge-68 & 1.06E-05 \\
\hline 03002915 & Am-241 & 3.36E-09 & 48000160 & Ga-68 (p) & 1.06E-05 \\
\hline 03002919 & Am-241 & 2.27E-06 & 48000160 & $\mathrm{Hg}-197 \mathrm{~m}$ & 1.05E-05 \\
\hline 03002919 & Pu-238 & $1.27 \mathrm{E}-06$ & 48000160 & $\mathrm{Hg}-197(p)$ & $1.05 E-05$ \\
\hline 03002919 & Pu-239 & 7.89E-06 & 48000160 & Se-75 & 8.84E-08 \\
\hline 03002920 & Am-241 & 7.75E-08 & 50000102 & Sr-90 & 5.75E-08 \\
\hline 03002920 & Pu-238 & 1.96E-08 & 50000102 & $Y-90(p)$ & 5.75E-08 \\
\hline 03002920 & Pu-239 & $2.45 E-07$ & 50003701 & Th-230 & 2.88E-09 \\
\hline 03002923 & Am-241 & 9.98E-09 & 50006903 & Pu-238 & $2.23 \mathrm{E}-10$ \\
\hline 03002923 & Pu-238 & 4.62E-08 & 53000303 & Ar-41 & $1.92 \mathrm{E}+00$ \\
\hline 03002923 & Th-230 & 2.53E-08 & 53000303 & C-11 & $4.60 \mathrm{E}+01$ \\
\hline 03002923 & $\mathrm{U}-234$ & 3.30E-06 & 53000303 & $\mathrm{Be}-7$ & $6.40 \mathrm{E}-05$ \\
\hline 03002923 & U-235 & 8.36E-08 & 53000303 & $\mathrm{Br}-76$ & 2.69E-05 \\
\hline 03002923 & $\mathrm{U}-238$ & $1.80 \mathrm{E}-07$ & 53000303 & $\mathrm{Br}-77$ & 2.11E-05 \\
\hline 03002923 & Pa-234m (p) & $1.80 \mathrm{E}-07$ & 53000303 & $\mathrm{Br}-82$ & 5.73E-05 \\
\hline 03002923 & Th-234 (p) & $1.80 \mathrm{E}-07$ & 53000303 & $\mathrm{Mn}-54$ & $1.98 \mathrm{E}-07$ \\
\hline 03002924 & Am-241 & 7.23E-08 & 53000303 & $\mathrm{Na}-22$ & 1.18E-07 \\
\hline 03002924 & Pu-238 & 1.57E-06 & 53000303 & $\mathrm{Na}-24$ & 1.27E-05 \\
\hline 03002924 & Pu-239 & 2.05E-07 & 53000303 & H-3(HTO) & $1.64 \mathrm{E}+01$ \\
\hline 03002924 & Sr-90 & 2.34E-08 & 53000702 & Ar-41 & $1.36 \mathrm{E}+01$ \\
\hline 03002924 & Y-90 (p) & 2.34E-08 & 53000702 & C-10 & $1.06 \mathrm{E}+00$ \\
\hline 03002924 & Th-228 & $2.24 \mathrm{E}-07$ & 53000702 & C-11 & $5.00 \mathrm{E}+02$ \\
\hline 03002924 & $U-234$ & 6.97E-06 & 53000702 & $\mathrm{~N}-13$ & $3.05 E+01$ \\
\hline 03002924 & U-235 & 3.48E-08 & 53000702 & $\mathrm{~N}-16$ & 9.46E-01 \\
\hline 03002928 & Am-241 & 2.98E-08 & 53000702 & O-14 & $2.02 E+00$ \\
\hline 03002928 & Pu-238 & 7.28E-07 & 53000702 & O-15 & $1.20 \mathrm{E}+02$ \\
\hline 03002928 & Pu-239 & $2.65 E-07$ & 53000702 & As-73 & 6.56E-06 \\
\hline 03002929 & None & $0.00 \mathrm{E}+00$ & 53000702 & $\mathrm{Be}-7$ & 5.23E-07 \\
\hline 03002932 & None & $0.00 \mathrm{E}+00$ & 53000702 & $\mathrm{Br}-76$ & 4.88E-04 \\
\hline 03002933 & None & $0.00 E+00$ & 53000702 & $\mathrm{Br}-77$ & $9.15 E-05$ \\
\hline 03002937 & Th-230 & $6.00 \mathrm{E}-10$ & 53000702 & $\mathrm{Br}-82$ & 2.33E-03 \\
\hline 03002944 & Am-241 & 7.01E-09 & 53000702 & $\mathrm{Hg}-197 \mathrm{~m}$ & 1.17E-03 \\
\hline 03002945 & None & $0.00 E+00$ & 53000702 & $\mathrm{Hg}-197(p)$ & 1.17E-03 \\
\hline 03002946 & Am-241 & 6.05E-09 & 53000702 & I-126 & 7.06E-07 \\
\hline 03010222 & None & $0.00 \mathrm{E}+00$ & 53000702 & $\mathrm{Na}-24$ & 5.48E-04 \\
\hline 16045005 & H-3(Gas) & $1.36 \mathrm{E}+01$ & 53000702 & Os-191 & 1.35E-05 \\
\hline 16045005 & H-3(HTO) & $3.39 \mathrm{E}+01$ & 53000702 & Se-75 & 1.62E-05 \\
\hline 48000107 & As-74 & 1.04E-06 & 53000702 & H-3(HTO) & $5.25 E+00$ \\
\hline 48000107 & $\mathrm{Br}-77$ & 2.76E-06 & 55000415 & None & $0.00 \mathrm{E}+00$ \\
\hline 48000107 & Ge-68 & 3.62E-03 & 55000416 & H-3(Gas) & $3.45 E+00$ \\
\hline 48000107 & Ga-68 (p) & $3.62 E-03$ & 55000416 & H-3(HTO) & $3.99 \mathrm{E}+00$ \\
\hline 48000107 & $\mathrm{Hg}-197 \mathrm{~m}$ & 1.49E-04 & 55000416 & Am-241 & 5.10E-10 \\
\hline 48000107 & $\mathrm{Hg}-197(p)$ & 1.49E-04 & 55000416 & Pu-239 & 8.59E-10 \\
\hline 48000107 & Se-75 & 1.08E-04 & \multicolumn{3}{|c|}{ See Table 2 notes, next page. } \\
\hline
\end{tabular}




\section{LANL Radionuclide Air Emissions Report}

Table 2 Notes:

Stacks at the Chemistry \& Metallurgy Research (CMR) facility identified as 03002915 through 03002933 are recorded in the RADAIR database as N3002915 through N3002933, to indicate measurements made with the New sampling systems, effective 2001.

Starting in 2006, particulate emissions from TA-55 stacks 55000415 and 55000416 are measured from new sample systems, which consist of four independent sample systems on each stack. The four samplers are identified as 5500415A, -B, -C, and -D; and 5500416A, -B, -C, and -D. Stack emissions data reported in this table represent average emission values measured from these four samplers. In the RADAIR database, these average emissions are given the stack ID 5500415X and 5500416X, with the "X" indicating the calculated average value from the four samples. The emissions of tritium (H-3, both HT and HTO forms) from the ES-16 stack use a different sample system, and references remain unchanged in the database.

Radionuclides with the designator "(p)" are short-lived progeny in secular equilibrium with their parent radionuclide; e.g., Ga-68 (progeny) is in equilibrium with Ge-68 (parent).

The term "None" in the Nuclide column indicates that there were no detectable emissions from this source for this calendar year. 
Table 3. 40-61.94(b)(7) User-Supplied Data-Monitored Stack Parameters

\begin{tabular}{|c|c|c|c|c|}
\hline StackID & Height (m) & Diameter (m) & Exit Velocity $(\mathbf{m} / \mathbf{s})$ & $\begin{array}{l}\text { Nearest } \\
\text { teorological } \\
\text { Tower }\end{array}$ \\
\hline 03002914 & 15.9 & 1.07 & 12.04 & TA-6 \\
\hline 03002915 & 15.9 & 1.05 & 10.58 & TA-6 \\
\hline 03002919 & 15.9 & 1.07 & 17.75 & TA-6 \\
\hline 03002920 & 15.9 & 1.07 & 24.31 & TA-6 \\
\hline 03002923 & 15.9 & 1.07 & 22.92 & TA-6 \\
\hline 03002924 & 15.9 & 1.06 & 9.58 & TA-6 \\
\hline 03002928 & 15.9 & 1.05 & 21.32 & TA-6 \\
\hline 03002929 & 15.9 & 1.07 & 23.75 & TA-6 \\
\hline 03002932 & 15.9 & 1.07 & 11.22 & TA-6 \\
\hline 03002933 & 15.9 & 1.06 & 26.42 & TA-6 \\
\hline 03002937 & 16.8 & 0.20 & 4.74 & TA-6 \\
\hline 03002944 & 16.5 & 1.52 & 8.65 & TA-6 \\
\hline 03002945 & 16.5 & 1.52 & 8.77 & TA-6 \\
\hline 03002946 & 16.5 & 1.88 & 6.40 & TA-6 \\
\hline 03010222 & 13.4 & 0.91 & 0.39 & TA-6 \\
\hline 16045005 & 18.3 & 1.18 & 9.59 & TA-6 \\
\hline 48000107 & 13.4 & 0.30 & 20.61 & TA-6 \\
\hline 48000154 & 13.1 & 0.91 & 6.13 & TA-6 \\
\hline 48000160 & 12.4 & 0.38 & 9.24 & TA-6 \\
\hline 50000102 & 15.5 & 1.82 & 11.36 & TA-6 \\
\hline 50003701 & 12.4 & 0.91 & 6.64 & TA-6 \\
\hline 50006903 & 10.5 & 0.31 & 6.75 & TA-6 \\
\hline 53000303 & 33.5 & 0.91 & 10.90 & TA-53 \\
\hline 53000702 & 13.1 & 0.91 & 7.98 & TA-53 \\
\hline 55000415 & 9.5 & 0.93 & 7.52 & TA-6 \\
\hline 55000416 & 9.5 & 0.94 & 11.31 & TA-6 \\
\hline
\end{tabular}


Table 4. 61.94(b)(7) User-Supplied Data-Monitored Stack ParametersNM State Plane Coordinates (NAD '83)

\begin{tabular}{|c|c|c|}
\hline StackID & Easting & Northing \\
\hline 03002914 & $1,619,176$ & $1,772,806$ \\
\hline 03002915 & $1,619,171$ & $1,772,805$ \\
\hline 03002919 & $1,619,252$ & $1,772,350$ \\
\hline 03002920 & $1,619,257$ & $1,772,352$ \\
\hline 03002923 & $1,618,691$ & $1,772,719$ \\
\hline 03002924 & $1,618,686$ & $1,772,718$ \\
\hline 03002928 & $1,618,774$ & $1,772,265$ \\
\hline 03002929 & $1,618,767$ & $1,772,265$ \\
\hline 03002932 & $1,619,268$ & $1,772,267$ \\
\hline 03002933 & $1,619,272$ & $1,772,269$ \\
\hline 03002937 & $1,618,966$ & $1,772,397$ \\
\hline 03002944 & $1,618,987$ & $1,772,121$ \\
\hline 03002945 & $1,618,977$ & $1,772,120$ \\
\hline 03002946 & $1,618,982$ & $1,772,121$ \\
\hline 03010222 & $1,618,354$ & $1,772,074$ \\
\hline 16045005 & $1,609,426$ & $1,760,910$ \\
\hline 48000107 & $1,623,591$ & $1,770,693$ \\
\hline 48000154 & $1,623,744$ & $1,770,650$ \\
\hline 48000160 & $1,623,613$ & $1,770,638$ \\
\hline 50000102 & $1,626,157$ & $1,769,086$ \\
\hline 50003701 & $1,625,757$ & $1,769,111$ \\
\hline 50006903 & $1,625,579$ & $1,769,065$ \\
\hline 53000303 & $1,638,133$ & $1,771,546$ \\
\hline 53000702 & $1,638,057$ & $1,771,054$ \\
\hline 55000415 & $1,624,870$ & $1,769,742$ \\
\hline 55000416 & $1,624,675$ & $1,769,550$ \\
\hline
\end{tabular}


Table 5. 40-61.94(b)(7) User-Supplied Data-Highest Off-Site Dose Location for Monitored Release Points

\begin{tabular}{|c|c|c|c|}
\hline StackID & $\begin{array}{c}\text { Associated } \\
\text { Meteorological } \\
\text { Tower } \\
\end{array}$ & $\begin{array}{c}\text { Distance to } \\
\text { LANL Highest } \\
\text { Dose Location (m) }\end{array}$ & $\begin{array}{c}\text { Direction to } \\
\text { LANL Highest } \\
\text { Dose Location } \\
\end{array}$ \\
\hline 03002914 & TA-06 & 6,002 & $\mathrm{E}$ \\
\hline 03002915 & TA-06 & 6,003 & $\mathrm{E}$ \\
\hline 03002919 & TA-06 & 5,990 & $\mathrm{E}$ \\
\hline 03002920 & TA-06 & 5,998 & $\mathrm{E}$ \\
\hline 03002923 & TA-06 & 6,151 & $\mathrm{E}$ \\
\hline 03002924 & TA-06 & 6,153 & E \\
\hline 03002928 & TA-06 & 6,137 & $\mathrm{E}$ \\
\hline 03002929 & TA-06 & 6,139 & $\mathrm{E}$ \\
\hline 03002932 & TA-06 & 5,987 & E \\
\hline 03002933 & TA-06 & 5,986 & $\mathrm{E}$ \\
\hline 03002937 & TA-06 & 6,075 & $\mathrm{E}$ \\
\hline 03002944 & TA-06 & 6,077 & $\mathrm{E}$ \\
\hline 03002945 & TA-06 & 6,080 & $\mathrm{E}$ \\
\hline 03002946 & TA-06 & 6,078 & $\mathrm{E}$ \\
\hline 03010222 & TA-06 & 6,270 & $\mathrm{E}$ \\
\hline 16045005 & TA-06 & 9,821 & ENE \\
\hline 48000107 & TA-06 & 4,758 & ENE \\
\hline 48000154 & TA-06 & 4,715 & ENE \\
\hline 48000160 & TA-06 & 4,755 & ENE \\
\hline 50000102 & TA-06 & 4,152 & ENE \\
\hline 50003701 & TA-06 & 4,263 & ENE \\
\hline 50006903 & TA-06 & 4,319 & ENE \\
\hline 53000303 & TA-53 & 806 & NNE \\
\hline 53000702 & TA-53 & 957 & NNE \\
\hline 55000415 & TA-06 & 4,456 & ENE \\
\hline 55000416 & TA-06 & 4,530 & ENE \\
\hline
\end{tabular}


Table 6. 40-61.94(b)(7) User-Supplied Data-Other Input Parameters

Description

Annual rainfall rate

Lid height

Annual ambient temperature

Absolute humidity

E-vertical temperature gradient

F-vertical temperature gradient

G-vertical temperature gradient

Food supply fraction - local vegetables

Food supply fraction - vegetable regional

Food supply fraction - vegetable imported

Food supply fraction - meat local

Food supply fraction - meat regional

Food supply fraction - meat imported

Food supply fraction - milk local

Food supply fraction - milk regional

Food supply fraction - milk imported

Ground surface roughness factor

\section{Value Units CAP88 Variable Name}

$\begin{array}{rcc}45 & \mathrm{~cm} / \mathrm{y} & \mathrm{RR} \\ 1600 & \mathrm{~m} & \mathrm{LIPO} \\ 9 & \mathrm{deg} \mathrm{C} & \mathrm{TA} \\ 5.5 & \mathrm{~g} / \mathrm{m}^{3} & \\ 0.02 & \mathrm{~K} / \mathrm{m} & \mathrm{TG} \\ 0.035 & \mathrm{~K} / \mathrm{m} & \mathrm{TG} \\ 0.035 & \mathrm{~K} / \mathrm{m} & \mathrm{TG} \\ 1 & \mathrm{~F} 1 \mathrm{~V} & \\ 0 & \mathrm{~F} 2 \mathrm{~V} & \\ 0 & \mathrm{~F} 3 \mathrm{~V} & \\ 1 & \mathrm{~F} 1 \mathrm{~B} & \\ 0 & \mathrm{~F} 2 \mathrm{~B} & \\ 0 & \mathrm{~F} 3 \mathrm{~B} & \\ 1 & \mathrm{~F} 1 \mathrm{M} & \\ 0 & \mathrm{~F} 2 \mathrm{M} & \\ 0 & \mathrm{~F} 3 \mathrm{M} & \\ 0.5 & \mathrm{GSCF} & \end{array}$




\section{Table 7. 40-61.94(b)(7) User-Supplied Data-Wind Frequency Arrays}

CAP88 Input Data for 2004-2008 TA-6 Meteorological Tower (95.0\% Data Completeness)

$\mathrm{N} A 0.000800 .000260 .000010 .000000 .000000 .00000$

NNE A 0.001400 .000460 .000010 .000000 .000000 .00000

$\mathrm{NE}$ A 0.002200 .000890 .000010 .000000 .000000 .00000

ENE A 0.004000 .001420 .000000 .000000 .000000 .00000

E A 0.004960 .002130 .000010 .000000 .000000 .00000

ESE A 0.004150 .001930 .000010 .000000 .000000 .00000

SE A 0.003440 .002090 .000000 .000000 .000000 .00000

SSE A 0.002590 .001810 .000010 .000000 .000000 .00000

S A 0.001690 .001150 .000000 .000000 .000000 .00000

SSW A 0.000890 .000640 .000010 .000000 .000000 .00000

SW A 0.000560 .000300 .000000 .000000 .000000 .00000

WSW A 0.000430 .000180 .000010 .000000 .000000 .00000

W A 0.000340 .000230 .000000 .000000 .000000 .00000

WNW A 0.000330 .000220 .000020 .000000 .000000 .00000

NW A 0.000360 .000200 .000020 .000000 .000000 .00000

NNW A 0.000460 .000310 .000020 .000000 .000000 .00000

N B 0.000260 .000220 .000000 .000000 .000000 .00000

NNE B 0.000430 .000360 .000000 .000000 .000000 .00000

$\mathrm{NE} B \quad 0.000620 .000970 .000000 .000000 .000000 .00000$

ENE B 0.001300 .001570 .000010 .000000 .000000 .00000

E B 0.001650 .002230 .000000 .000000 .000000 .00000

ESE B 0.001130 .002380 .000010 .000000 .000000 .00000

SE B 0.001040 .002580 .000000 .000000 .000000 .00000

SSE B 0.000790 .002510 .000000 .000000 .000000 .00000

S B 0.000450 .001340 .000010 .000000 .000000 .00000

SSW B 0.000230 .000570 .000020 .000000 .000000 .00000

SW B 0.000090 .000300 .000020 .000000 .000000 .00000

WSW B 0.000100 .000270 .000010 .000000 .000000 .00000

W B 0.000090 .000200 .000030 .000000 .000000 .00000

WNW B 0.000100 .000210 .000060 .000000 .000000 .00000

NW B 0.000090 .000240 .000050 .000000 .000000 .00000

NNW B 0.000130 .000180 .000030 .000000 .000000 .00000

N C 0.000240 .000520 .000070 .000000 .000000 .00000

$\mathrm{NNE} C 0.000630 .001210 .000060 .000000 .000000 .00000$

$\mathrm{NE} C 0.000960 .002680 .000060 .000000 .000000 .00000$

ENE C 0.001630 .004110 .000060 .000000 .000000 .00000

E C 0.002200 .004630 .000030 .000000 .000000 .00000

ESE C 0.001540 .005420 .000050 .000000 .000000 .00000

SE C 0.001350 .006920 .000140 .000000 .000000 .00000

SSE C 0.001230 .008560 .000440 .000000 .000000 .00000

S C 0.000890 .005350 .000760 .000010 .000000 .00000

SSW C 0.000540 .002150 .000730 .000010 .000000 .00000

SW C 0.000300 .001030 .000360 .000000 .000000 .00000

WSW C 0.000230 .000760 .000350 .000010 .000000 .00000

W C 0.000170 .000580 .000230 .000020 .000000 .00000

WNW C 0.000160 .000660 .000240 .000020 .000000 .00000

NW C 0.000130 .000520 .000440 .000010 .000000 .00000

NNW C 0.000190 .000540 .000190 .000010 .000000 .00000

N D 0.004070 .007210 .003350 .000940 .000100 .00000

NNE D 0.004640 .010880 .006240 .002230 .000210 .00000

$\mathrm{NE}$ D 0.003990 .010080 .004260 .000380 .000020 .00000

ENE D 0.004530 .007190 .001330 .000090 .000010 .00000 


\section{Table 7 (Continued)}

E D 0.005660 .005790 .000440 .000010 .000000 .00000

ESE D 0.004480 .006530 .000720 .000060 .000000 .00000

SE D 0.004360 .009790 .002270 .000170 .000000 .00000

SSE D 0.004920 .018210 .011980 .000890 .000010 .00000

S D 0.005240 .023400 .032760 .005180 .000110 .00001

SSW D 0.004880 .020140 .027770 .008450 .000600 .00003

SW D 0.004070 .012420 .017200 .008480 .001500 .00021

WSW D 0.004010 .009620 .012910 .009660 .002040 .00045

W D 0.003670 .008360 .013370 .011710 .003010 .00035

WNW D 0.003380 .007380 .013330 .010850 .004820 .00134

NW D 0.003880 .009130 .011270 .007340 .001500 .00020

NNW D 0.004230 .007130 .004810 .001340 .000050 .00000

$\mathrm{N}$ E 0.001930 .004250 .002260 .000000 .000000 .00000

NNE E 0.001590 .003960 .002090 .000000 .000000 .00000

$\mathrm{NE}$ E 0.001200 .002010 .000440 .000000 .000000 .00000

ENE E 0.001060.000760.000050.000000.000000.00000

E E 0.001120 .000420 .000020 .000000 .000000 .00000

ESE E 0.000800 .000600 .000020 .000000 .000000 .00000

SE E 0.000960 .001090 .000070 .000000 .000000 .00000

SSE E 0.001440 .002260 .000150 .000000 .000000 .00000

S E 0.001890 .008770 .002190 .000000 .000000 .00000

SSW E 0.002070 .016930 .004760 .000000 .000000 .00000

SW E 0.002030 .014040 .009010 .000000 .000000 .00000

WSW E 0.002140 .006350 .004710 .000000 .000000 .00000

W E 0.001540 .003390 .002180 .000000 .000000 .00000

WNW E 0.001930.004100.004760.000000.000000.00000

NW E 0.001820 .007510 .006290 .000000 .000000 .00000

NNW E 0.002080 .005410 .001560 .000000 .000000 .00000

N F 0.006350 .007490 .000590 .000000 .000000 .00000

NNE F 0.004410 .002660 .000110 .000000 .000000 .00000

$\mathrm{NE}$ F 0.002570 .000850 .000000 .000000 .000000 .00000

ENE F 0.001400 .000170 .000000 .000000 .000000 .00000

E F 0.001120 .000090 .000000 .000000 .000000 .00000

ESE F 0.000960 .000110 .000000 .000000 .000000 .00000

SE F 0.001130 .000180 .000000 .000000 .000000 .00000

SSE F 0.001610 .000380 .000010 .000000 .000000 .00000

S F 0.002590 .001330 .000030 .000000 .000000 .00000

SSW F 0.003860 .003950 .000130 .000000 .000000 .00000

SW F 0.006530 .013980 .001120 .000000 .000000 .00000

WSW F 0.007700 .026920 .004060 .000000 .000000 .00000

W F 0.007430 .025710 .003340 .000000 .000000 .00000

WNW F 0.006940 .022190 .003650 .000000 .000000 .00000

NW F 0.007600 .025450 .001560 .000000 .000000 .00000

NNW F 0.007620 .013880 .000530 .000000 .000000 .00000 


\section{Table 7 (continued)}

CAP88 Input Data for 2009 TA-53 Meteorological Tower (99.97\% Data Completeness)

N A 0.000970 .000170 .000000 .000000 .000000 .00000

NNE A 0.001540 .000230 .000000 .000000 .000000 .00000

$\mathrm{NE}$ A 0.003080 .000940 .000030 .000000 .000000 .00000

ENE A 0.003280 .001710 .000000 .000000 .000000 .00000

E A 0.003880 .002310 .000000 .000000 .000000 .00000

ESE A 0.002570 .002230 .000030 .000000 .000000 .00000

SE A 0.002770 .002110 .000000 .000000 .000000 .00000

SSE A 0.002480 .001540 .000030 .000000 .000000 .00000

S A 0.001310 .001570 .000000 .000000 .000000 .00000

SSW A 0.000660 .000940 .000000 .000000 .000000 .00000

SW A 0.000630 .000600 .000000 .000000 .000000 .00000

WSW A 0.000340 .000490 .000000 .000000 .000000 .00000

WA 0.000230 .000200 .000000 .000000 .000000 .00000

WNW A 0.000290 .000340 .000030 .000000 .000000 .00000

NW A 0.000430 .000140 .000000 .000000 .000000 .00000

NNW A 0.000310 .000140 .000000 .000000 .000000 .00000

N B 0.000170 .000110 .000000 .000000 .000000 .00000

NNE B 0.000540 .000230 .000000 .000000 .000000 .00000

$\mathrm{NE} \mathrm{B} 0.000860 .001000 .000000 .000000 .000000 .00000$

ENE B 0.001200 .002200 .000000 .000000 .000000 .00000

E B 0.000970 .002480 .000030 .000000 .000000 .00000

ESE B 0.000890 .002060 .000000 .000000 .000000 .00000

SE B 0.000940 .002280 .000000 .000000 .000000 .00000

SSE B 0.000630 .002460 .000030 .000000 .000000 .00000

S B 0.000690 .001480 .000000 .000000 .000000 .00000

SSW B 0.000290 .001030 .000060 .000000 .000000 .00000

SW B 0.000090 .000630 .000000 .000000 .000000 .00000

WSW B 0.000090 .000430 .000030 .000000 .000000 .00000

W B 0.000090 .000340 .000000 .000000 .000000 .00000

WNW B 0.000000 .000260 .000000 .000000 .000000 .00000

NW B 0.000110 .000230 .000030 .000000 .000000 .00000

NNW B 0.000170 .000170 .000000 .000000 .000000 .00000

$\mathrm{N} \mathrm{C} 0.000400 .000490 .000140 .000000 .000000 .00000$

$\mathrm{NNE} C 0.001110 .001680 .000460 .000000 .000000 .00000$

$\mathrm{NE} C 0.001430 .003030 .000400 .000000 .000000 .00000$

ENE C 0.001660 .005710 .000230 .000000 .000000 .00000

E C 0.001630 .006310 .000060 .000000 .000000 .00000

ESE C 0.001280 .005650 .000000 .000000 .000000 .00000

SE C 0.001030 .005050 .000140 .000000 .000000 .00000

SSE C 0.000890 .005200 .000260 .000000 .000000 .00000

S C 0.000710 .005340 .000430 .000000 .000000 .00000

SSW C 0.000310 .002310 .000460 .000000 .000000 .00000

SW C 0.000170 .000910 .000310 .000000 .000000 .00000

WSW C 0.000170 .000740 .000570 .000000 .000000 .00000

W C 0.000110 .000800 .000710 .000000 .000000 .00000

WNW C 0.000110 .000510 .000800 .000000 .000000 .00000

NW C 0.000090 .000340 .000200 .000030 .000000 .00000

NNW C 0.000090 .000200 .000090 .000000 .000000 .00000

N D 0.005050 .008110 .010760 .002540 .000260 .00009

NNE D 0.005910 .011310 .011560 .004400 .000490 .00000

$\mathrm{NE}$ D 0.004850 .011130 .005170 .001140 .000000 .00000

ENE D 0.004880 .010620 .002880 .000110 .000000 .00000 


\section{Table 7 (Continued)}

E D 0.005880 .010250 .001630 .000000 .000000 .00000

ESE D 0.004050 .007540 .001030 .000000 .000000 .00000

SE D 0.003030 .006770 .001370 .000110 .000060 .00000

SSE D 0.002710 .010530 .007620 .001770 .000430 .00000

S D 0.003400 .015500 .028980 .012050 .000490 .00000

SSW D 0.002600 .014850 .036110 .027410 .003480 .00043

SW D 0.002280 .011110 .024070 .013620 .002800 .00040

WSW D 0.002080 .006480 .015620 .011620 .003030 .00051

W D 0.001570 .006400 .015220 .010110 .002170 .00131

WNW D 0.002260 .005540 .008820 .006420 .001660 .00029

NW D 0.003080 .003450 .004510 .004250 .000690 .00003

NNW D 0.003280 .004140 .004430 .002310 .000690 .00014

$\mathrm{N}$ E 0.003970 .009020 .002660 .000000 .000000 .00000

$\mathrm{NNE}$ E 0.003650 .007190 .003140 .000000 .000000 .00000

$\mathrm{NE}$ E 0.002030 .004170 .001000 .000000 .000000 .00000

ENE E 0.001170 .002000 .000600 .000000 .000000 .00000

E E 0.001030 .001630 .000090 .000000 .000000 .00000

ESE E 0.000800 .001260 .000090 .000000 .000000 .00000

SE E 0.000830 .001110 .000090 .000000 .000000 .00000

SSE E 0.000740 .001910 .000540 .000000 .000000 .00000

S E 0.000940 .004600 .005250 .000000 .000000 .00000

SSW E 0.001140 .010280 .026470 .000000 .000000 .00000

SW E 0.001260 .018100 .018610 .000000 .000000 .00000

WSW E 0.001800 .009280 .013590 .000000 .000000 .00000

W E 0.001340 .008450 .013500 .000000 .000000 .00000

WNW E 0.001540 .008360 .004310 .000000 .000000 .00000

NW E 0.002200 .005110 .002310 .000000 .000000 .00000

NNW E 0.002540 .006220 .003080 .000000 .000000 .00000

N F 0.005910 .003430 .000140 .000000 .000000 .00000

NNE F 0.006480 .003030 .000140 .000000 .000000 .00000

NE F 0.006790 .001880 .000060 .000000 .000000 .00000

ENE F 0.004430 .001630 .000030 .000000 .000000 .00000

E F 0.003340 .000800 .000000 .000000 .000000 .00000

ESE F 0.003200.000710.000000.000000.000000.00000

SE F 0.002970 .001030 .000000 .000000 .000000 .00000

SSE F 0.003370 .001430 .000060 .000000 .000000 .00000

S F 0.003770 .004650 .000310 .000000 .000000 .00000

SSW F 0.005710.008170.002000.000000.000000.00000

SW F 0.004050 .005620 .000510 .000000 .000000 .00000

WSW F 0.003850 .008050 .003430 .000000 .000000 .00000

W F 0.003600 .010050 .005280 .000000 .000000 .00000

WNW F 0.004970.009710.001140.000000.000000.00000

NW F 0.004820 .003570 .000540 .000000 .000000 .00000

NNW F 0.005680 .003740 .000630 .000000 .000000 .00000 


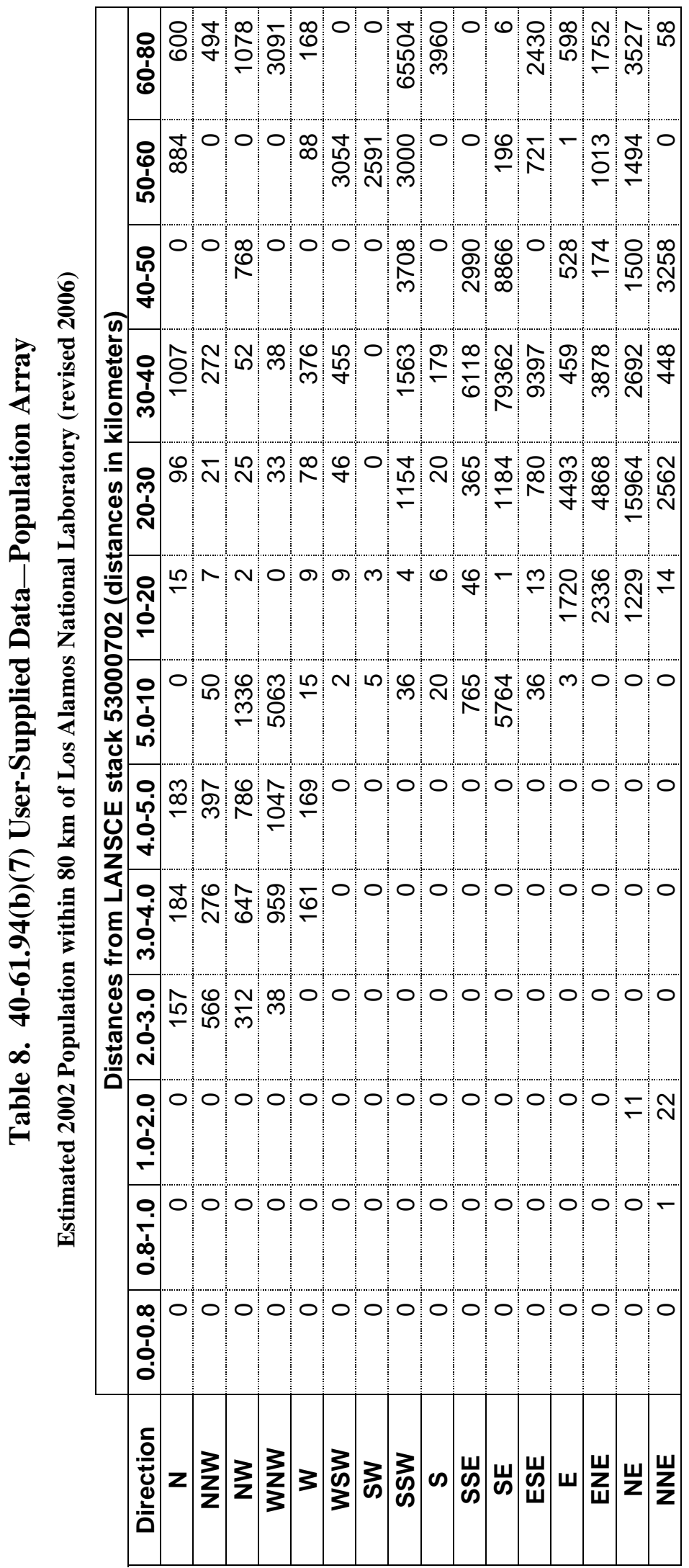


Table 9. 40-61.94(b)(7) User-Supplied Data-Modeling Parameters for LANL Non-Point Sources

LANL Air Activation Sources

\begin{tabular}{|c|c|c|c|c|c|}
\hline Source & Radionuclide & $\begin{array}{c}\text { Emission } \\
\text { (Ci) }\end{array}$ & $\begin{array}{c}\text { Area of } \\
\text { Source } \\
\left(\mathbf{m}^{\mathbf{3}}\right)\end{array}$ & $\begin{array}{l}\text { Distance to } \\
\text { LANL } \\
\text { Maximum } \\
\text { Dose } \\
\text { Location } \\
\text { (m) }\end{array}$ & $\begin{array}{c}\text { Direction to } \\
\text { LANL } \\
\text { Maximum } \\
\text { Dose } \\
\text { Location } \\
\end{array}$ \\
\hline \multirow[t]{2}{*}{ TA-53 Switchyard } & ${ }^{41} \mathrm{Ar}$ & $4.12 \mathrm{E}-01$ & 484 & 774 & NNE \\
\hline & ${ }^{11} \mathrm{C}$ & $9.90 \mathrm{E}+00$ & 484 & 774 & NNE \\
\hline \multirow[t]{2}{*}{ TA-53-1L Service Area } & ${ }^{41} \mathrm{Ar}$ & $1.97 \mathrm{E}+00$ & 1.0 & 943 & NNE \\
\hline & ${ }^{11} \mathrm{C}$ & $4.73 \mathrm{E}+01$ & 1.0 & 943 & NNE \\
\hline
\end{tabular}


Table 10. Environmental Data-Compliance Stations

2009 Effective Dose Equivalent (net in mrem) measured at air sampling locations around LANL

\begin{tabular}{|c|c|c|c|c|c|c|c|c|c|c|}
\hline $\begin{array}{l}\text { New } \\
\text { Site } \\
\text { ID }\end{array}$ & $\begin{array}{l}\text { Old } \\
\text { Site } \\
\text { ID }\end{array}$ & Site Name & H-3 & $\begin{array}{l}\text { Am- } \\
241\end{array}$ & $\begin{array}{l}\text { Pu- } \\
238\end{array}$ & $\begin{array}{l}\text { Pu- } \\
239\end{array}$ & U-234 & U-235 & U-238 & $\begin{array}{c}\text { Total } \\
\text { (mrem) }\end{array}$ \\
\hline 149 & 06 & 48th Street & 0.000 & 0.003 & 0.000 & 0.000 & 0.000 & 0.002 & 0.000 & 0.005 \\
\hline 166 & 08 & McDonalds & 0.001 & 0.006 & 0.000 & 0.001 & 0.007 & 0.002 & 0.011 & 0.028 \\
\hline 114 & 09 & LA Airport & 0.001 & 0.000 & 0.000 & 0.000 & 0.005 & 0.001 & 0.006 & 0.014 \\
\hline 157 & 10 & Eastgate & 0.005 & 0.000 & 0.000 & 0.000 & 0.015 & 0.004 & 0.010 & 0.035 \\
\hline 137 & 11 & Well PM-1 & 0.003 & 0.001 & 0.000 & 0.000 & 0.002 & 0.001 & 0.001 & 0.009 \\
\hline 151 & 12 & Royal Crest Trailer Court & 0.001 & 0.000 & 0.001 & 0.000 & 0.007 & 0.001 & 0.008 & 0.018 \\
\hline 119 & 13 & Rocket Park & 0.006 & 0.004 & 0.000 & 0.000 & 0.007 & 0.001 & 0.006 & 0.024 \\
\hline 121 & 14 & Pajarito Acres & 0.003 & 0.000 & 0.000 & 0.000 & 0.004 & 0.002 & 0.001 & 0.010 \\
\hline 167 & 15 & White Rock Fire Station & 0.006 & 0.000 & 0.001 & 0.000 & 0.003 & 0.001 & 0.002 & 0.014 \\
\hline 168 & 16 & White Rock Nazarene Ch. & 0.011 & 0.001 & 0.000 & 0.000 & 0.003 & 0.002 & 0.002 & 0.019 \\
\hline 133 & 17 & Bandelier Fire Lookout & 0.000 & 0.005 & 0.002 & 0.000 & 0.006 & 0.002 & 0.002 & 0.017 \\
\hline 291 & 18 & DP Rd - West Entrance & 0.039 & 0.000 & 0.006 & 0.000 & 0.014 & 0.002 & 0.018 & 0.040 \\
\hline 344 & 19 & Hilltop House & 0.000 & 0.005 & 0.000 & 0.000 & 0.010 & 0.002 & 0.020 & 0.037 \\
\hline 169 & 20 & TA-21 Area B & 0.003 & 0.002 & 0.001 & 0.021 & 0.008 & 0.002 & 0.006 & 0.043 \\
\hline 345 & 21 & Canyon School & 0.000 & 0.000 & 0.000 & 0.000 & 0.010 & 0.003 & 0.024 & 0.037 \\
\hline 307 & 24 & TA-16 & 0.005 & 0.000 & 0.000 & 0.000 & 0.009 & 0.002 & 0.006 & 0.022 \\
\hline 172 & 32 & LA County Landfill & 0.004 & 0.002 & 0.006 & 0.001 & 0.042 & 0.004 & 0.040 & 0.100 \\
\hline 317 & 42 & A15 - West End & 0.003 & 0.000 & 0.003 & 0.002 & 0.009 & 0.002 & 0.014 & 0.034 \\
\hline 318 & 43 & East Road Fire Station & 0.002 & 0.000 & 0.001 & 0.000 & 0.008 & 0.001 & 0.014 & 0.026 \\
\hline 319 & 44 & New Beginnings Church & 0.002 & 0.005 & 0.000 & 0.003 & 0.018 & 0.002 & 0.022 & 0.051 \\
\hline 320 & 46 & Hedge Row, East Rd. & 0.000 & 0.003 & 0.012 & 0.002 & 0.009 & 0.002 & 0.014 & 0.041 \\
\hline 210 & 60 & LA Canyon & 0.003 & 0.002 & 0.000 & 0.003 & 0.005 & 0.001 & 0.004 & 0.019 \\
\hline 211 & 61 & LA Hospital & 0.001 & 0.000 & 0.001 & 0.000 & 0.006 & 0.001 & 0.004 & 0.012 \\
\hline 212 & 62 & Crossroads Bible Church & 0.001 & 0.001 & 0.005 & 0.001 & 0.021 & 0.003 & 0.025 & 0.057 \\
\hline 213 & 63 & Monte Rey South & 0.002 & 0.000 & 0.000 & 0.000 & 0.003 & 0.001 & 0.002 & 0.008 \\
\hline 257 & 66 & Los Alamos Inn - South & 0.002 & 0.003 & 0.000 & 0.124 & 0.003 & 0.001 & 0.008 & 0.142 \\
\hline 262 & 67 & TA-3 Research Park & 0.001 & 0.002 & 0.000 & 0.000 & 0.007 & 0.001 & 0.006 & 0.018 \\
\hline 290 & 68 & LA Airport Road & 0.000 & 0.013 & 0.000 & 0.000 & 0.007 & 0.002 & 0.008 & 0.031 \\
\hline 326 & 71 & DP - Fire Station & 0.003 & 0.001 & 0.001 & 0.000 & 0.011 & 0.003 & 0.012 & 0.032 \\
\hline 327 & 72 & DP - Ace & 0.001 & 0.011 & 0.004 & 0.006 & 0.008 & 0.002 & 0.011 & 0.044 \\
\hline 328 & 73 & DP - Monitor & 0.001 & 0.000 & 0.002 & 0.005 & 0.012 & 0.004 & 0.014 & 0.039 \\
\hline 329 & 74 & A15 - West Center & 0.004 & 0.008 & 0.002 & 0.013 & 0.011 & 0.002 & 0.017 & 0.057 \\
\hline 330 & 75 & A15 - East Center & 0.011 & 0.003 & 0.003 & 0.009 & 0.008 & 0.005 & 0.015 & 0.055 \\
\hline 331 & 79 & A15 - East End & 0.001 & 0.000 & 0.003 & 0.013 & 0.032 & 0.003 & 0.015 & 0.068 \\
\hline 206 & 90 & Eastgate - Backup & 0.002 & 0.008 & 0.000 & 0.000 & 0.013 & 0.002 & 0.013 & 0.039 \\
\hline
\end{tabular}

Note 1: In 2009, the Airnet program began using three-digit number identifications for all stations, reflecting the tracking database "Master Site ID." Both this new number and the more common two-digit identifier is shown in the table above.

Note 2: Stations 172 (Los Alamos County Landfill) and 257 (Los Alamos Inn - South) are reviewed further in the section on "Highest EDE Determination," above. 
Table 11. Environmental Data-Compliance Stations

2009 Analytical Completeness and Air Sampler Operation Summary

\begin{tabular}{|c|c|c|c|c|c|c|c|c|c|c|}
\hline $\begin{array}{c}\text { New } \\
\text { Site } \\
\text { ID }\end{array}$ & $\begin{array}{c}\text { Old } \\
\text { Site } \\
\text { ID }\end{array}$ & Site Name & H-3 & $\begin{array}{l}\text { Am- } \\
241\end{array}$ & $\begin{array}{l}\text { Pu- } \\
238\end{array}$ & $\begin{array}{l}\text { Pu- } \\
239\end{array}$ & $\begin{array}{l}\text { U- } \\
234\end{array}$ & $\begin{array}{c}\text { U- } \\
235\end{array}$ & $\begin{array}{l}\text { U- } \\
238\end{array}$ & $\begin{array}{l}\text { Percent } \\
\text { run time }\end{array}$ \\
\hline 149 & 06 & 48th Street & 100 & 100 & 100 & 100 & 100 & 100 & 100 & 98.7 \\
\hline 166 & 08 & McDonalds & 100 & 100 & 100 & 100 & 100 & 100 & 100 & 96.8 \\
\hline 114 & 09 & Los Alamos Airport & 100 & 100 & 100 & 100 & 100 & 100 & 100 & 99.6 \\
\hline 157 & 10 & Eastgate & 100 & 100 & 100 & 100 & 100 & 100 & 100 & 98.4 \\
\hline 137 & 11 & Well PM-1 & 100 & 100 & 100 & 100 & 100 & 100 & 100 & 99.0 \\
\hline 151 & 12 & Royal Crest Trailer Ct & 100 & 100 & 100 & 100 & 100 & 100 & 100 & 99.6 \\
\hline 119 & 13 & Rocket Park & 100 & 100 & 100 & 100 & 100 & 100 & 100 & 99.6 \\
\hline 121 & 14 & Pajarito Acres & 84.6 & 100 & 100 & 100 & 100 & 100 & 100 & 99.6 \\
\hline 167 & 15 & White Rock Fire Station & 100 & 100 & 100 & 100 & 100 & 100 & 100 & 99.6 \\
\hline 168 & 16 & White Rock Nazarene Ch. & 100 & 100 & 100 & 100 & 100 & 100 & 100 & 99.2 \\
\hline 133 & 17 & Bandelier Fire Lookout & 100 & 100 & 100 & 100 & 100 & 100 & 100 & 98.5 \\
\hline 291 & 18 & DP Rd - West Entrance & 94.7 & 100 & 100 & 100 & 100 & 100 & 100 & 99.9 \\
\hline 344 & 19 & Hilltop House & 93.3 & 100 & 100 & 100 & 100 & 100 & 100 & 98.9 \\
\hline 169 & 20 & TA-21 Area B & 100 & 100 & 100 & 100 & 100 & 100 & 100 & 99.8 \\
\hline 345 & 21 & Canyon School & 66.7 & 100 & 100 & 100 & 100 & 100 & 100 & 98.6 \\
\hline 307 & 24 & TA-16 & 100 & 100 & 100 & 100 & 100 & 100 & 100 & 99.0 \\
\hline 172 & 32 & LA County Landfill & 100 & 100 & 100 & 100 & 100 & 100 & 100 & 98.6 \\
\hline 317 & 42 & A15 - West End & 100 & 100 & 100 & 100 & 100 & 100 & 100 & 99.0 \\
\hline 318 & 43 & East Road Fire Station & 100 & 100 & 100 & 100 & 100 & 100 & 100 & 99.5 \\
\hline 319 & 44 & New Beginnings Church & 100 & 100 & 100 & 100 & 100 & 100 & 100 & 99.5 \\
\hline 320 & 46 & Hedge Row, East Rd. & 100 & 100 & 100 & 100 & 100 & 100 & 100 & 99.5 \\
\hline 210 & 60 & LA Canyon & 100 & 100 & 100 & 100 & 100 & 100 & 100 & 99.6 \\
\hline 211 & 61 & LA Hospital & 100 & 100 & 100 & 100 & 100 & 100 & 100 & 99.6 \\
\hline 212 & 62 & Crossroads Bible Church & 100 & 100 & 100 & 100 & 100 & 100 & 100 & 99.6 \\
\hline 213 & 63 & Monte Rey South & 100 & 100 & 100 & 100 & 100 & 100 & 100 & 96.8 \\
\hline 257 & 66 & Los Alamos Inn - South & 100 & 100 & 100 & 100 & 100 & 100 & 100 & 99.0 \\
\hline 262 & 67 & TA-3 Research Park & 92.3 & 100 & 100 & 100 & 100 & 100 & 100 & 99.5 \\
\hline 290 & 68 & LA Airport Road & 100 & 100 & 100 & 100 & 100 & 100 & 100 & 97.9 \\
\hline 326 & 71 & DP - Fire Station & 100 & 100 & 100 & 100 & 100 & 100 & 100 & 98.7 \\
\hline 327 & 72 & DP - Ace & 100 & 100 & 100 & 100 & 100 & 100 & 100 & 96.8 \\
\hline 328 & 73 & DP - Monitor & 100 & 100 & 100 & 100 & 100 & 100 & 100 & 99.6 \\
\hline 329 & 74 & A15 - West Center & 100 & 100 & 100 & 100 & 100 & 100 & 100 & 98.4 \\
\hline 330 & 75 & A15 - East Center & 100 & 100 & 100 & 100 & 100 & 100 & 100 & 99.0 \\
\hline 331 & 79 & A15 - East End & 100 & 100 & 100 & 100 & 100 & 100 & 100 & 99.6 \\
\hline 206 & 90 & Eastgate - Backup & 100 & 100 & 100 & 100 & 100 & 100 & 100 & 99.6 \\
\hline
\end{tabular}


Table 12. LANSCE Monthly Assessments, Comparison, and Facility Summary

\begin{tabular}{|c|c|c|}
\hline Description & StackID & $\begin{array}{l}\text { Dose at East } \\
\text { Gate Receptor }\end{array}$ \\
\hline LANSCE stack January GMAP & 53000702 & None \\
\hline LANSCE stack February GMAP & 53000702 & None \\
\hline LANSCE stack March GMAP & 53000702 & None \\
\hline LANSCE stack April GMAP & 53000702 & None \\
\hline LANSCE stack May GMAP & 53000702 & $6.14 \mathrm{E}-04$ \\
\hline LANSCE stack June GMAP & 53000702 & $9.31 \mathrm{E}-03$ \\
\hline LANSCE stack July GMAP & 53000702 & $1.37 \mathrm{E}-02$ \\
\hline LANSCE stack August GMAP & 53000702 & $1.82 \mathrm{E}-02$ \\
\hline LANSCE stack September GMAP & 53000702 & $1.28 \mathrm{E}-02$ \\
\hline LANSCE stack October GMAP & 53000702 & $1.82 \mathrm{E}-02$ \\
\hline LANSCE stack November GMAP & 53000702 & $5.92 \mathrm{E}-02$ \\
\hline LANSCE stack December GMAP & 53000702 & $8.12 \mathrm{E}-02$ \\
\hline Sum of monthly GMAP runs for this stack & 53000702 & $2.13 \mathrm{E}-01$ \\
\hline GMAP single annual analysis for this stack & 53000702 & $1.94 \mathrm{E}-01$ \\
\hline
\end{tabular}

To be conservative, the maximum value of the two above methods will be used for all further reporting of GMAP emissions from the main LANSCE stack 53000702.

\begin{tabular}{lcc|}
\hline SUMMARY OF LANSCE FACILITY DOSE & & \\
\hline LANSCE stack GMAP (see above) & 53000702 & $2.13 \mathrm{E}-01$ \\
LANSCE stack PVAP & 53000702 & $3.54 \mathrm{E}-03$ \\
LANSCE Non-CAP88 Radionuclides & 53000702 & $2.26 \mathrm{E}-05$ \\
LANSCE stack GMAP & 53000303 & $7.59 \mathrm{E}-03$ \\
LANSCE stack PVAP & 53000303 & $4.78 \mathrm{E}-03$ \\
LANSCE Non-CAP88 Radionuclides & 53000303 & None \\
LANSCE Fugitive Emissions - Switchyard & $530003 \mathrm{SY}$ & $8.71 \mathrm{E}-03$ \\
LANSCE Fugitive Emissions - 1L Service Area & $5300071 \mathrm{~L}$ & $2.88 \mathrm{E}-02$
\end{tabular}

LANSCE facility summary:

2.67E-01

GMAP = Gaseous Mixed Activation products; short-lived radioactive gases (e.g., C-11, O-15, Ar-41).

PVAP = Particulate \& Vapor Activation Products (e.g., Na-24, Br-76).

Note: all CAP88 assessments above are annual assessments, with the exception of the monthly GMAP analyses for stack

53000702, as described above. 


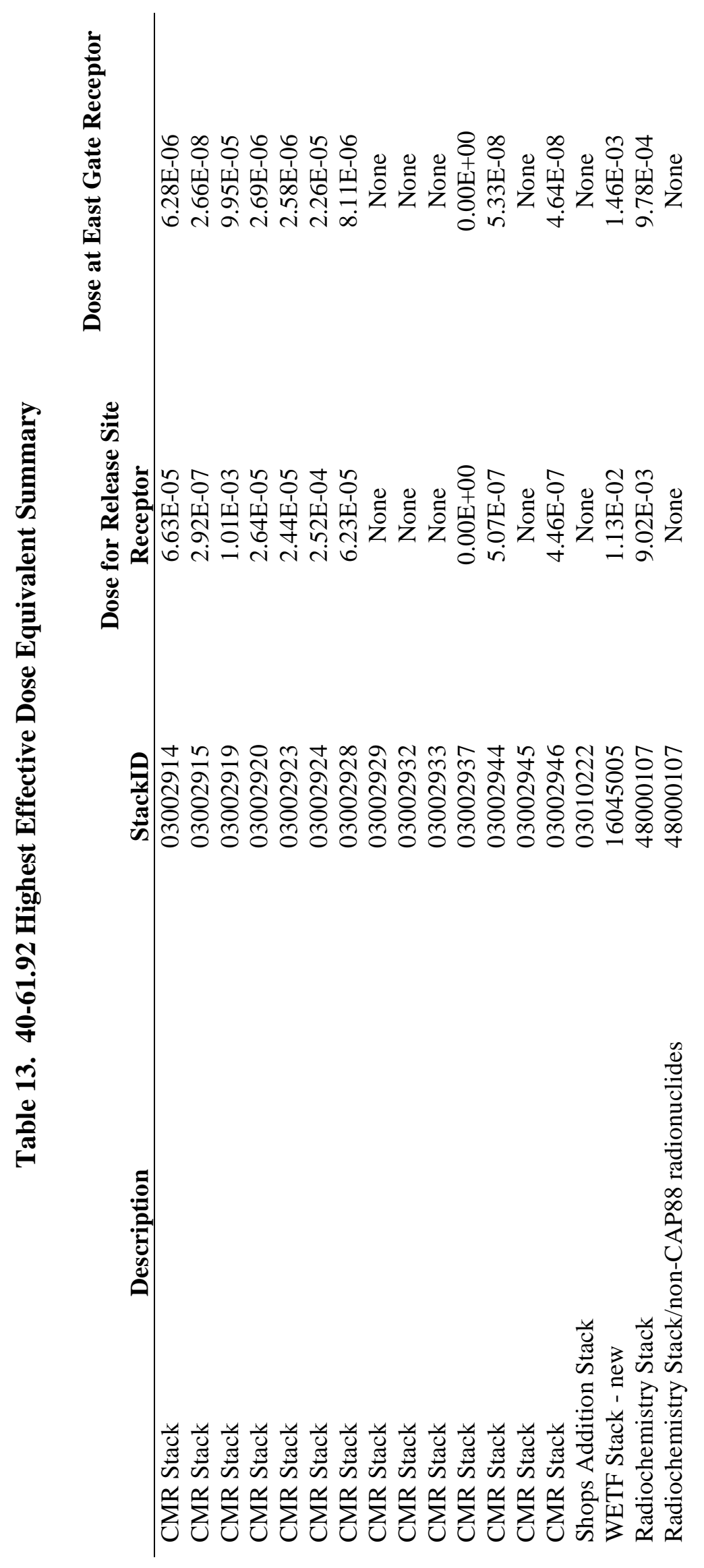




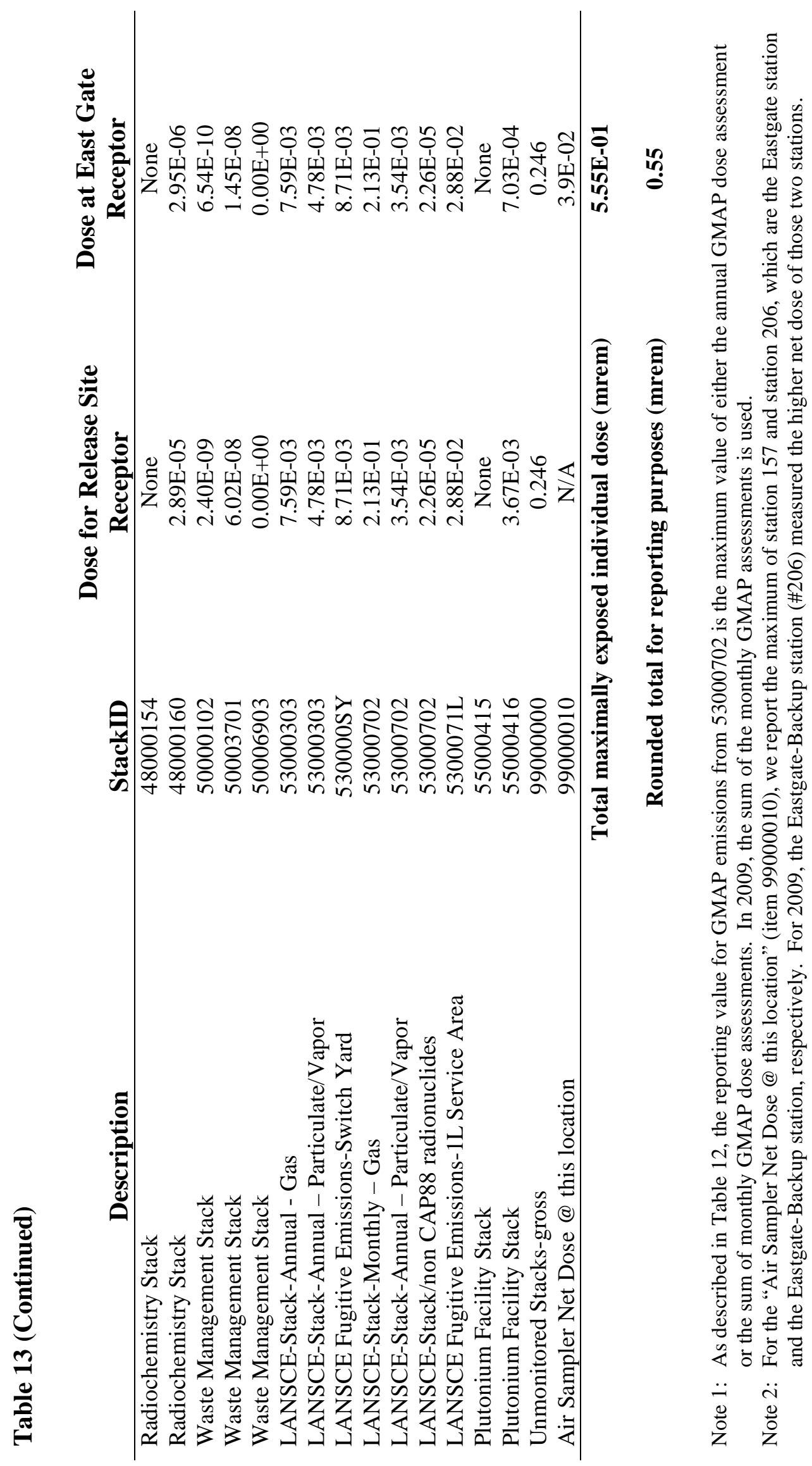




\subsection{4(b)(9) Certification}

I certify under penalty of law that I have personally examined and am familiar with the information submitted herein and based on my inquiry of those individuals immediately responsible for obtaining the information, I believe that the submitted information is true, accurate, and complete. I am aware that there are significant penalties for submitting false information including the possibility of fine and imprisonment. See 18 U.S.C. 1001.

Signature: (Signature on File)

Date:

Donald L. Winchell, Jr., Owner

Manager

Los Alamos Site Office

National Nuclear Security Administration

U.S. Department of Energy

Signature: (Signature on File) Date:

J. Chris Cantwell, Operator

Associate Director

Environment, Safety, Health and Quality Division

Los Alamos National Security, LLC

Los Alamos National Laboratory 


\section{References}

1. Los Alamos National Laboratory, "Environmental Surveillance at Los Alamos during 2008," LA14369-ENV, September 2009.

2. Los Alamos National Laboratory, “SWEIS Yearbook-2007,” LA-UR-09-01653, 2009.

3. U.S. Department of Energy, "Site-Wide Environmental Impact Statement for Continued Operation of the Los Alamos National Laboratory" DOE/EIS-0380 (available URL: www.doeal.gov/laso/NEPASWEIS.aspx), 2009.

4. R. Sturgeon, "2009 Radioactive Materials Usage Survey for Unmonitored Point Sources," ENV-ES:10-107, June 15, 2010 (pending final publication at time of report development).

5. Los Alamos National Laboratory Procedure, “Air Quality Reviews,” P408, December 2007.

6. U.S. Environmental Protection Agency, Federal Register, Vol. 60, No. 107, June 5, 1995.

7. Los Alamos National Laboratory Procedure, "Evaluating New Diffuse Sources and New Receptors for AIRNET Coverage,” ESH-17-238, R0, December 2001.

8. Letter to Mr. George Brozowski, Radiation Program Manager, Environmental Protection Agency from Mr. Steve Fong, Office of Environment, Department of Energy, May 11, 2001.

9. Frank Marcinowski, Acting Director, Radiation Protection Division, "Criteria to Determine Whether a Leased Facility at Department of Energy (DOE) is Subject to Subpart H," Office of Radiation and Indoor Air, U.S. Environmental Protection Agency, March 26, 2001.

10 K. F. Eckerman, A. B. Wolbarst, and A. C. B. Richardson, Federal Guidance Report No. 11, "Limiting Values of Radionuclide Intake and Air Concentration and Dose Conversion Factors for Inhalation, Submersion, and Ingestion," Office of Radiation Programs, U.S.

Environmental Protection Agency, Washington, D.C., 1988.

11. K. F. Eckerman and J. C. Ryman, Federal Guidance Report No. 12, "External Exposures to Radionuclides in Air, Water, and Soil Exposure-to-Dose Coefficients for General Application,” U.S. Environmental Protection Agency, Washington, D.C., 1993.

12. K. F. Eckerman, R. W. Leggett, C. B. Nelson, J. S. Puskin, and A. C. B. Richardson, Federal Guidance Report No. 13, "Cancer Risk Coefficients for Environmental Exposure to Radionuclides,” U.S. Environmental Protection Agency, Washington, D.C., 1999.

13. Los Alamos National Laboratory Procedure, "Dose Factors for Non-CAPP88 Radionuclides," ENV-EAQ-512, November 2009.

14. Los Alamos National Laboratory, "2009 Annual Source Term for Radionuclide Air Emissions," ENV-ES:10-104, June 3, 2010. 
15 Los Alamos National Laboratory Procedure, “Air Pathway Dose Assessment," ENV-EAQ-502, September 2009.

16. U.S. Environmental Protection Agency, "National Emission Standards for Emissions of Radionuclides Other than Radon from Department of Energy Facilities," Code of Federal Regulations, Title 40, Part 61.90, Subpart H, 1989.

17. Bart Eklund, "Measurements of Emission Fluxes from Technical Area 54, Areas G and L," Radian Corporation report, Austin, Texas, 1995.

18. Los Alamos National Laboratory, "Performance Assessment and Composite Analysis for Los Alamos National Laboratory Materials Disposal Area G,” LA-UR-97-85, 1997. 
2009 LANL Radionuclide Air Emissions Report

LA-14423

Page 42 
This report has been reproduced directly from the best available copy. It is available electronically on the Web (http://www.doe.gov/bridge).

Copies are available for sale to U.S. Department of Energy employees and contractors from:

Office of Scientific and Technical Information

P.O. Box 62

Oak Ridge, TN 37831

(865) 576-8401

Copies are available for sale to the public from: National Technical Information Service

U.S. Department of Commerce

5285 Port Royal Road

Springfield, VA 22161

(800) 553-6847 
- Los Alamos NATIONAL LABORATORY

EST.1943 